(C) 2021, The Authors. Published by Elsevier Inc. and Fass Inc. on behalf of the American Dairy Science Association ${ }^{\circledR}$. This is an open access article under the CC BY-NC-ND license (http://creativecommons.org/licenses/by-nc-nd/4.0/).

\title{
The effects of organic grass and grass-birdsfoot trefoil pastures on Jersey heifer development: Herbage characteristics affecting intake
}

\author{
Marcus F. Rose, ${ }^{1} \odot$ Blair L. Waldron, ${ }^{2 *} \odot$ S. Clay Isom, ${ }^{3} \odot$ Michael D. Peel, ${ }^{2} \odot$ Kara J. Thornton, ${ }^{3} \odot$ \\ Rhonda L. Miller, ${ }^{4} \odot$ Kerry A. Rood, ${ }^{3} \odot$ Jacob A. Hadfield, ${ }^{3} \odot$ Jennifer Long, ${ }^{4} \odot$ Bracken Henderson, ${ }^{5}$ \\ and J. Earl Creech ${ }^{1}$ (I) \\ ${ }^{1}$ Plants, Soils, and Climate Department, Utah State University, Logan 84322-4820 \\ ${ }^{2}$ Forage and Range Research Laboratory, USDA, Agricultural Research Service, Logan, UT 84322-6300 \\ ${ }^{3}$ Animal, Dairy, and Veterinary Sciences Department, Utah State University, Logan 84322-4815 \\ ${ }^{4}$ Applied Sciences, Technology and Education Department, Utah State University, Logan 84322-2300 \\ ${ }^{5}$ Franklin County Office, University of Idaho Extension, Preston 83263
}

\section{ABSTRACT}

Low dietary energy and decreased intake of herbage have been attributed to the reduced performance of grazing dairy cattle. We hypothesized that grasses with inherently greater energy would interact in a complementary way with condensed tannins (CT) in birdsfoot trefoil to increase herbage intake by grazing dairy heifers. Eight pasture treatments comprising high-sugar perennial ryegrass (Lolium perenne L.), orchardgrass (Dactylis glomerata L.), meadow bromegrass (Bromus riparius Rehmann), and tall fescue [Schendonorus arundinaceus (Schreb.) Dumort] were established in Lewiston, Utah as monocultures and binary mixtures with birdsfoot trefoil (Lotus corniculatus L.; BFT). Pasture treatments were rotationally stocked by Jersey heifers for 105 d in 2017 and 2018, and herbage samples were collected pre- and postgrazing for each 7-d grazing period and analyzed for herbage mass, nutritive value, and apparent herbage intake. We observed differences among pasture treatments in herbage quantity and nutritive value, as well as differences in herbage intake by grazing Jersey heifers. On average, grass-BFT mixtures had greater herbage intake than grass monocultures, and every grass-BFT treatment individually had greater herbage intake than their respective grass monocultures. Using multivariate analyses, we determined that approximately $50 \%$ of the variation in herbage intake was due to nutritive and physical herbage characteristics, with the most explanatory being characteristics related to fiber and energy, followed by those related to the percent of BFT in the herbage. Grass monocultures exhibited a range of inherent dietary energy, but there was indication that an imbalance of energy to crude

Received September 2, 2020.

Accepted March 22, 2021

*Corresponding author: blair.waldron@usda.gov protein (e.g., protein deficient) reduced intake of grass monocultures. Moreover, there was some evidence of a complementary effect between increased dietary energy and $\mathrm{CT}$; however, low $\mathrm{CT}$ levels made it impossible to determine the effect of $\mathrm{CT}$ on herbage intake per se. This study confirmed that chemical and physical characteristics inherent to different pasture species have a large effect on herbage intake by grazing cattle. Pastures planted to binary mixtures of nutritious grasses and birdsfoot trefoil increase herbage intake of temperate pastures by grazing Jersey heifers.

Key words: dairy heifer, dry matter intake, grasslegume mixture, grazing, herbage nutritive value, pasture

\section{INTRODUCTION}

Pasture-based dairies and organic milk production are becoming more prevalent, with organic milk production being the fastest growing segment of organic agriculture (McBride and Greene, 2009; AgMRC, $2015)$. Over $60 \%$ of organic dairies use pastures as their primary $(\geq 50 \%)$ source of forage, and $90 \%$ use pastures for at least $25 \%$ of their forage (McBride and Greene, 2009; AgMRC, 2015). Organic milk companies often promote their product based upon the health and environmental benefits of milk from cows grazing pasture (Anon, 2020a) and usually require at least 120 grazing days per year for both lactating cows and replacement heifers (Anon, 2020b). However, milk production was $32 \%$ lower in organic dairies using the highest amount of pasture forage (75-100\%) compared with those using $25 \%$ or less pasture forage (McBride and Greene, 2009). Research has shown that low forage DMI by grazing dairy cows is a major factor limiting milk production (Bargo et al., 2003). Producers have also observed that dairy cattle appear to be more selective grazers than beef cattle, with many dairy cattle showing strong pref- 
erence for some pasture plants, resulting in even lower DMI of nonpreferred traditional pasture species such as tall fescue (G. Bingham, Dairy Exec. Committee Organic Valley Coop., Weston, Idaho, personal communication).

Pasture performance can be improved by introducing legumes into grass pastures (Stephenson and Posler, 1988; Hoveland et al., 1991). When grown in mixtures, perennial forage legumes can supply nitrogen to grasses (Mallarino et al., 1990; Nyfeler et al., 2011), potentially maintaining high grass forage yields with reduced nitrogen fertilizer (Cox et al., 2017). Grass-legume pastures can also improve livestock performance due to improved forage nutritive value. Birdsfoot trefoil (Lotus corniculatus L.; BFT) is of particular interest because it is a nonbloating legume and contains condensed tannins (CT). Moderate CT concentrations reportedly enhance forage nutritive value by reducing rumen bacterial protein degradation and increasing protein degradation in the intestine, without reducing fiber digestion or voluntary intake by grazing ruminants (Min et al., 2003; Piluzza et al., 2014). Multiple researchers have reported greater steer ADG, as well as increased total grazing days, when grazing tall fescueBFT trefoil mixtures compared with nitrogen-fertilized tall fescue monocultures (Hoveland et al., 1981; Wen et al., 2002; Waldron et al., 2020). Cows that graze BFT monoculture pastures have also shown higher DMI and milk production when compared with animals on grass pastures (Harris et al., 1998; Woodward et al., 2000; MacAdam et al., 2015).

Recently, a team of scientists conducted grass-legume pasture research at Utah State University. They reported that beef steers have better ADG when grazing tall fescue-legume mixtures than tall fescue monocultures, with the BFT mixture resulting in the highest gains and overall net profit (Waldron et al., 2020). Forage nutritive value was improved and forage mass was only slightly less for the grass-legume mixtures compared with fertilized tall fescue (Waldron et al., 2020), with small-plot studies indicating that certain grass-legume mixtures could be more productive than fertilized grass monocultures (Cox et al., 2017). Furthermore, digestion studies show that grass-BFT mixtures produce less ammonia-nitrogen and methane (Noviandi et al., 2014b). Overall, studies show that increased herbage-based dietary energy is needed in grass and CT-containing legume mixture pastures to further improve utilization of CP (Noviandi et al., 2012, 2014a) and livestock growth performance (Waldron et al., 2020).

"High-sugar" grasses with elevated water-soluble carbohydrates (WSC) have been touted as having concurrent increased digestibility and ME (Miller et al., 2001;
Edwards et al., 2007; Smith et al., 2007; Waghorn, 2007). These high-sugar perennial ryegrass cultivars have also been shown to increase DMI in dairy and beef cattle (Lee et al., 2002; Moorby et al., 2006), which can partially be explained by increased rumen degradation rate, leading to reduced feed retention time and fewer limitations on DMI (Miller et al., 2001). Thus, a possible tool to simultaneously increase dietary energy levels and DMI of grass-legume pastures is using highsugar grasses. However, WSC levels in perennial ryegrass varieties have shown large fluctuations depending on the geographic location, time of year, soil moisture content, night temperatures, or day length and temperature (Parsons et al., 2004; Cosgrove et al., 2007, 2014; Robins and Alan Lovatt, 2016). Furthermore, with few exceptions, high-sugar grasses, especially high-sugar orchardgrass cultivars, have not been widely evaluated in the irrigated pastures of the temperate United States (Robins and Alan Lovatt, 2016), nor have these highenergy grasses been extensively studied when planted in mixture with a CT-containing legume such as BFT. Therefore, we undertook this study to investigate the potential to increase herbage intake by grazing binary mixtures of various grasses with BFT. We hypothesized that low levels of CT in BFT would interact in a complimentary way with grasses that had greater inherent energy to further improve herbage intake compared with other mixtures. Specific objectives were to (1) determine if grass-BFT pastures resulted in greater herbage intake by dairy cattle compared with grassmonoculture pastures and (2) elucidate which herbage characteristics largely contributed to differences in herbage intake, including if there was a complimentary effect between dietary energy and low levels of CT.

\section{MATERIALS AND METHODS}

\section{Pasture Treatments and Pastures}

Grazing terminology in this paper is based on Allen et al. (2011). This experiment was conducted at the Utah State University Intermountain Pasture Research Farm $\left(41^{\circ} 57^{\prime} 01.85^{\prime \prime} \mathrm{N}, 111^{\circ} 52^{\prime} 15.75^{\prime \prime} \mathrm{W}\right.$, elevation 1,369 $\mathrm{m}, 46 \mathrm{~cm}$ annual precipitation, and 56.1 precipitation days per year) located near Lewiston, Utah. The soils at the site were a Kidman fine sandy loam (coarseloamy, mixed, superactive, mesic Calcic Haploxerolls) and Lewiston fine sandy loam (coarse-loamy, mixed, superactive, mesic Calcic Haploxerolls). The site is within the semiarid Central Great Basin region of the western United States, characterized by hot, dry summers, and most of the annual precipitation as snowfall (Figure 1). In this particular area (Cache county, Utah), the 
precipitation from winter-time snowfall is stored in reservoirs and used in the summer for irrigated crop production (Utah Climate Center, 2018). The experiment was arranged in a randomized complete block design with 8 pasture treatments in 3 blocks. Pasture treatments were endophyte-free tall fescue ("Fawn;" TF), meadow bromegrass ("Cache;" MB), high-sugar orchardgrass ("Quickdraw;" OG), and high-sugar perennial ryegrass ("Amazon;" PR) in monoculture and
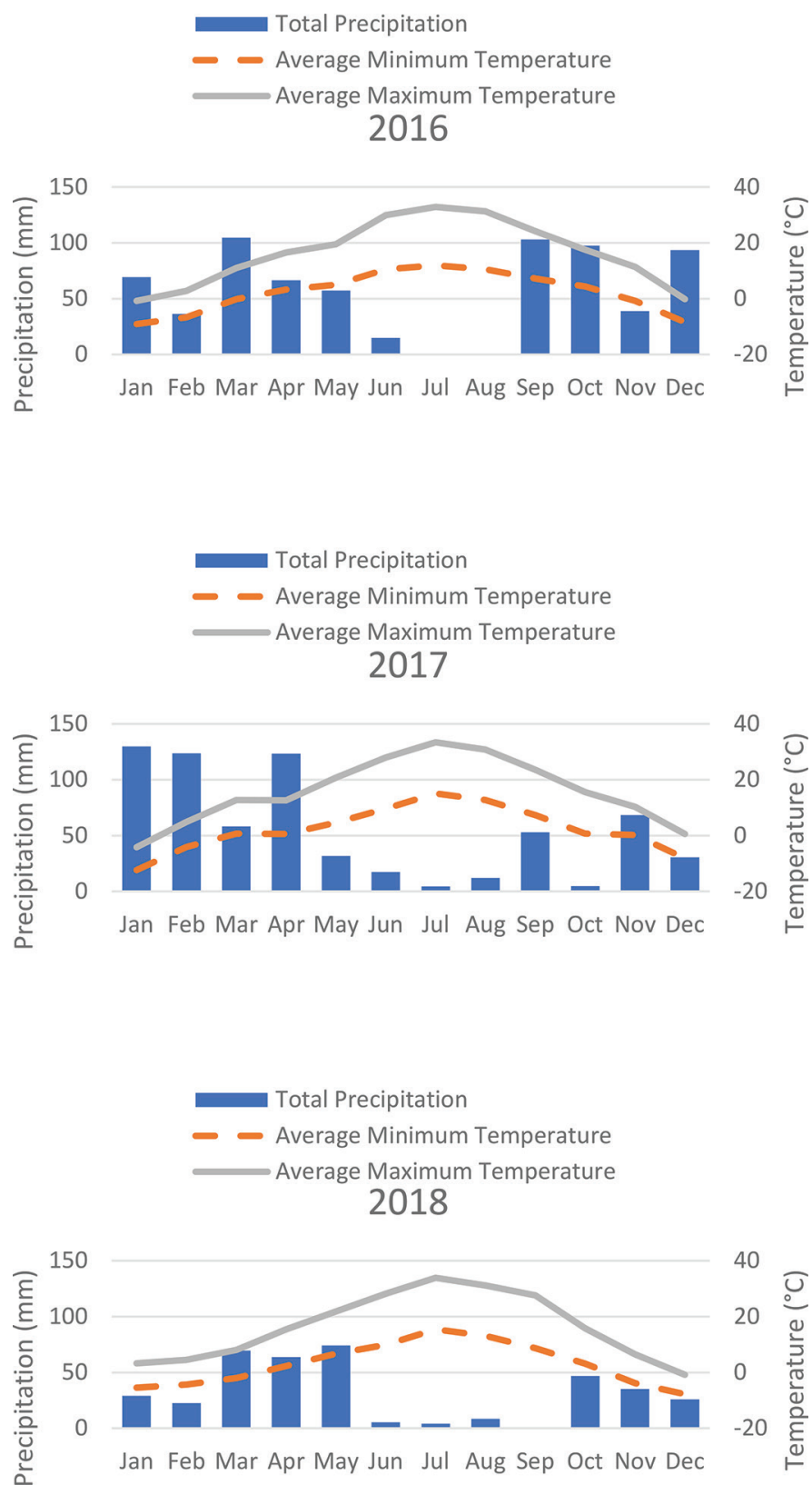

Figure 1. Total monthly precipitation and average minimum and maximum monthly temperatures in 2016, 2017, and 2018 for dairy heifer grazing study in Lewiston, Utah (Utah Climate Center, station name: Richmond, Station ID: USC00427271). as binary mixtures with BFT ("Pardee"). Seeding occurred in June 2015 with a Great Plains drill (Great Plains Ag) with double disk openers spaced $15.3 \mathrm{~cm}$ apart. Before planting, the pastures were prepared with conventional tillage equipment. For grass monocultures, $\mathrm{TF}, \mathrm{MB}$, and $\mathrm{PR}$ were seeded at $16.8 \mathrm{~kg}$ of pure live seed/ha and $\mathrm{OG}$ at $15.1 \mathrm{~kg}$ of pure live seed/ha. In binary mixtures, $\mathrm{TF}, \mathrm{MB}$, and $\mathrm{PR}$ were seeded at 10.1 $\mathrm{kg}$ of pure live seed/ha, and OG was seeded at $9 \mathrm{~kg}$ of pure live seed/ha. The BFT was seeded at $6.7 \mathrm{~kg}$ of pure live seed/ha in all the grass-legume treatments. The BFT was seeded separately from the grasses to ensure proper depth (i.e., 1.0 and $0.5 \mathrm{~cm}$ for grasses and BFT, respectively; Jensen et al., 2001). As per the recommendation of Waldron et al. (2020), our goal was to get 30 to $40 \% \mathrm{BFT}$ in the herbage (by weight), and these seeding rates were based upon prior studies that achieved this proportion (Cox et al., 2017; Waldron et al., 2020).

Pastures of each treatment were considered the experimental unit and consisted of 0.45 ha (i.e., 8 treatments $\times 3$ blocks $=24$ experimental units, totaling 10.7 ha for the entire experimental area) divided evenly into five 0.09-ha paddocks with a single strand of poly-wire charged with a battery-powered fence energizer (Gallagher). The study was conducted using organic dairy grazing protocols; therefore, no treatment received commercial fertilizer. However, in 2017 and 2018, approved organic sources of nitrogen were applied to the treatments at yearly rates of 91 and $28 \mathrm{~kg}$ of nitrogen/ ha for grass monocultures and mixtures, respectively, as described herein. Chilean nitrate (sodium nitrate, 15-02, N-P-K; SQM) was applied at $28 \mathrm{~kg}$ of nitrogen/ha in April to all treatments (both monoculture and mixtures). In addition, grass monocultures also received a second application of $28 \mathrm{~kg}$ of nitrogen/ha of Chilean nitrate in July, and further received $35 \mathrm{~kg}$ of nitrogen/ ha in the form of hydrolyzed poultry feathers in June 2017 and March 2018 (12.8\% nitrogen) as a slow-release source of nitrogen. Pastures were sprinkler irrigated regularly from mid-May to mid-September each year with $7.6 \mathrm{~cm}$ of water applied in 12-h applications every 14 to 20 d (e.g., approximately $100 \%$ evapotranspiration replacement). In 2016, pastures were mechanically harvested in June, and then a preliminary grazing study was conducted throughout the rest of the growing season. Due to differences in how the forage sampling and grazing was conducted, including timing of such events, data from 2016 were not included in the analyses.

\section{Livestock Grazing}

Livestock used in the study were 81 (per year) Jersey dairy heifers, with mean initial BW of $209 \pm 47$ and 183 
$\pm 72 \mathrm{~kg}$ in 2017 and 2018, respectively. Animals were cared for with the approval, and in accordance with the guidelines, of the Institutional Animal Care and Use Committee at Utah State University (IACUC protocol \#2777 and \#10063). Three heifers (testers) were randomly allocated to each of the 8 pasture treatments (TF, MB, OG, PR, TF+BFT, MB+BFT, OG+BFT, and $\mathrm{PR}+\mathrm{BFT}$ ) within each block. Grazing was initiated on the same calendar date for all treatments, when most grasses had reached the E0 stem elongation stage (Moore et al., 1991) and were approximately $25 \mathrm{~cm}$ in height (e.g., mid-May). In addition, 3 replicates of 3 control feedlot heifers were fed a TMR formulated to meet the nutritional needs of an ADG target of 0.8 $\mathrm{kg} / \mathrm{d}$. Feed offered and refused each day was dried and weighed to calculate DMI.

A fixed stocking rate of 6.7 heifers/ha (i.e., 3 heifers/0.45 ha experimental unit) was used throughout the study. This stocking rate was determined based upon presumed herbage intake of $2.5 \% \mathrm{BW}$, previous estimates of these grasses, and grass $+\mathrm{BFT}$ mixtures herbage mass (Cox et al., 2017), and the objective to ensure excess herbage (e.g., high herbage allowance) to emphasize the nutritive value effects on DMI and heifer performance (Baudracco et al., 2010; Sollenberger and Vanzant, 2011). There were no herbage target end-points for grazing a particular paddock. Rather, rotational stocking was used with a set stocking period of $7 \mathrm{~d}$, followed by a rest period of $28 \mathrm{~d}$ for each of the 5 paddocks, such that the entire rotation cycle was 35 d. There were 3 rotation cycles each year; therefore, heifers were on pasture for a total of $105 \mathrm{~d}$ (May 17 to August 30, 2017 and May 16 to August 29, 2018). In a few instances, a tester was removed due to illness and no longer used in herbage intake measures, and a spare heifer was placed in the treatment to keep stocking rate the same for each treatment and rotation. The total BW of heifers in each experimental unit (e.g., pasture) were recorded, and later converted to standard animal units (AU) to equalize all treatments over the grazing season. The standard AU was defined as a $250-\mathrm{kg}$ Jersey heifer (i.e., mean final heifer BW), and thus AU was calculated as the total observed metabolic live BW (i.e., $\mathrm{BW} \mathrm{kg}^{0.75}$ ) divided by the metabolic live $\mathrm{BW}$ for a 250-kg heifer (i.e., $62.9 \mathrm{~kg}$; Allen et al., 2011). Paddocks were mowed to a uniform stubble height of $15 \mathrm{~cm}$ with a rotary mower at the end of each 7-d stocking period to reduce confounding effects of remaining residue on herbage mass and nutritive value in subsequent grazing rotations. All heifers had access to water and trace mineral supplement. Heifers were weighed at the beginning of the study, and after each 35-d rotation cycle to determine BW as reported by Hadfield et al. (2021).

\section{Herbage Evaluation and Herbage Intake}

Pregrazing and postgrazing herbage samples were collected throughout the experiment $24 \mathrm{~h}$ before (pre-) and immediately after (post-) heifer rotation to the next paddock, by hand-clipping 4 random quadrats $\left(0.25 \mathrm{~m}^{2}\right)$ per paddock to a stubble height of 7.6 or $3.8 \mathrm{~cm}$, in 2017 and 2018, respectively. Stubble height was lowered in 2018 to reduce sampling inconsistencies. Postgrazing samples were taken immediately adjacent to the pre-grazing samples, unless it was in an area where heifers had defecated or lain. Herbage samples were placed into a paper bag and dried to a constant weight at $60^{\circ} \mathrm{C}$ and weighed to determine herbage mass (as DM). Pre- and postgrazing compressed sward heights $(\mathrm{cm})$ were measured each time herbage was clipped with a rising plate meter (Jenquip) directly over each pre- and postgrazing clipped quadrat and as the mean of 30 measurements taken in a " $\mathrm{w}$ " pattern throughout each paddock. Individual quadrat herbage mass measurements were regressed against respective rising plate meter measurements, forcing a zero intercept as described by Dillard et al. (2016), to develop herbage mass prediction equations within each year and treatment $\left(\mathrm{R}^{2}\right.$ ranging from 0.78-0.97). Paddock-based pre- and postgrazing herbage mass were then predicted using these equations and the 30-measurement rising plate meter mean herbage height. Because of the tall height of the herbage in the first rotation cycle, rising plate meter measurements were not reliable for paddocks 3, 4, and 5 in 2017 and paddocks 4 and 5 in 2018 and not used in the calibration equations. An estimate of daily herbage accumulation rate ( $\mathrm{kg} / \mathrm{ha}$ per day) during the grazing period was determined as

\section{Daily herbage accumulation $=$}

$\left\{\left[\operatorname{Rot}_{n}\right.\right.$ pregrazing herbage mass $/\left(\right.$ Rot $_{n}$ pregrazing HT

- Rot $_{n}$ sample stubble HT $\left.)\right] \times\left(\right.$ Rot $_{n}$ pregrazing HT

- Rot $_{n-1}$ postgrazing mowed stubble HT)\}/

28-d rest period,

where $\operatorname{Rot}_{n}$ represents each successive grazing rotation cycle and HT is compressed height. The same daily herbage accumulation was assumed for both rotation cycles 1 and 2 .

Herbage mass was converted to herbage allowance as described by Sollenberger et al. (2005) for rotational stocking. Briefly, herbage allowance ( $\mathrm{kg}$ of herbage $/ \mathrm{kg}$ of BW) was calculated as

Herbage allowance $=\frac{\frac{\text { pregrazing herbage mass }}{\mathrm{BW}}+\frac{\text { postgrazing herbage mass }}{\mathrm{BW}}}{2}$, 
where heifer BW was that from the beginning of each rotation cycle. This method of "mid-point" calculation addresses questions concerning point-in-time requirements for herbage allowance, and accounts for changes in herbage mass during the 7-d stocking period (Sollenberger et al., 2005).

Dried herbage samples were ground to pass through a 1-mm screen using a Thomas Wiley Laboratory Model 4 mill (Arthur H. Thomas Co.) and were scanned with a Foss XDS near-infrared reflectance spectroscopy (NIRS) instrument (Foss) to determine herbage nutritive value. The appropriate 2018 NIRS Forage and Feed Testing Consortium (Hillsboro) equations were used (i.e., grass hay-18gh50 for monocultures, and mixed hay-18mh50 for the grass-BFT mixtures) resulting in estimates of $\mathrm{CP}, \mathrm{NDF}, \mathrm{ADF}, \mathrm{ADL}$, in vitro true digestibility (IVTD), 48-h NDF digestibility (NDFD), fatty acids, and ash. Total digestible nutrients (TDN) were calculated using the appropriate formulas for grass monocultures or grass-legume mixtures (as per Saha et al., 2010; e.g., not ADF-based). Metabolizable energy was calculated as TDN $\times 0.04409 \times 0.82(\mathrm{NRC}, 2000)$.

An existing grass-legume NIRS equation developed by Waldron et al. (2020) was calibrated using WINisi version 4.10.0.15326 (Foss Analytical A/S, www .fossanalytics.com) to predict the proportion of BFT (e.g., \% BFT) in the herbage. One-half of all clipped grass-BFT samples were hand-separated, of which $50 \%$ were used for additional equation development and $50 \%$ were used for equation validation. Following hand separation, grass and BFT components were dried and weighed to determine actual percent of BFT in the herbage mass. Components were then ground separately, and a subsample recombined at the original ratio was scanned for NIRS analysis. The validation for percent legume was $\mathrm{R}^{2}=0.94$, and standard error of prediction was 6.20. Condensed tannin concentrations in the pregrazing BFT were predicted using the separated BFT samples and a previously developed NIRS equation (Grabber et al., 2014, 2015). The equation resulted in prediction statistics of $R^{2}=0.88$, and standard error of prediction $=3.79$ (not validated with an independent sampling). Concentrations of $\mathrm{CT}$ in the herbage (\%) were calculated as $\mathrm{BFT} \mathrm{CT} \times \% \mathrm{BFT}$, assuming that BFT CT concentration did not change significantly between pre-grazing and postgrazing samples. Consistent with herbage allowance, all herbage nutritive value data, herbage height, percent of BFT, and percent of $\mathrm{CT}$ in herbage data are presented on a DM basis and as the mid-point value between pre- and postgrazing for each 7-d grazing period.

Estimates of apparent herbage intake were based upon herbage disappearance between the pre-grazing and postgrazing herbage mass estimates for each pad- dock (Macoon et al., 2003), with adjustments made for daily herbage accumulation and grazing efficiency. Grazing efficiency (the proportion of herbage consumed by livestock compared with the total that disappears due to all other activities) increases as grazing pressure increases (Allison et al., 1982; Smart et al., 2010; Baudracco et al., 2013). Estimates of grazing efficiency (on a paddock basis) were calculated by regressing modified herbage allowance data from this study (modified as $\mathrm{kg}$ of herbage $/ \mathrm{kg}$ of BW per day) using an equation developed from the Allison et al. (1982) comparisons of herbage allowance and grazing efficiency (i.e., grazing efficiency $=105.11-463.30 \times$ modified herbage allowance; $\left.R^{2}=0.93\right)$. Overall, herbage intake was estimated as

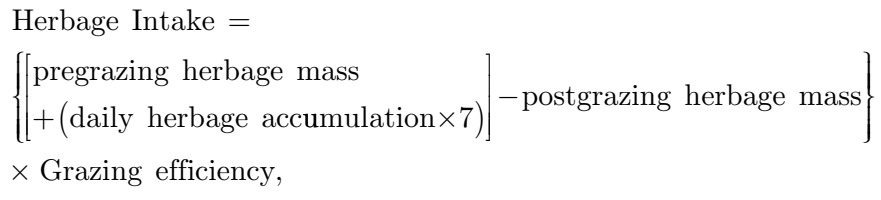

and reported as kilograms per hectare, kilogram per heifer per day, and additionally as kilogram per AU per day to account for differences in heifer growth among pasture treatments (an AU was defined as a 250-kg Jersey heifer, see livestock grazing). For comparison, predicted herbage intake based upon nutritive value was calculated using (1) a weighted average of the grass and legume DMI equations in Saha et al. (2010) and (2) the all-forage diet DMI equation for growing cattle in NRC (2000).

\section{Statistical Analysis}

Pastures were defined as the experimental units, and the 5 paddocks within each pasture experimental unit were observational or sampling units. Therefore, the mean of all herbage samples and apparent herbage intake calculations within a rotation $(n=20)$ were used for statistical analysis. Herbage data and herbage intake were analyzed across years as a randomized complete block design using the MIXED procedure of SAS (version 9.4, SAS Institute Inc.). Pasture type (monoculture vs. mixture), pasture treatment within type, and rotation cycle were considered fixed effects, whereas year and block were considered random. Rotation cycle was considered a repeated measure, and the best covariance models for each trait (most often heterogeneous compound symmetry) were determined and used in the analysis (Littell et al., 2006). Mean comparisons were made using Fisher's protected least significant difference test at the $P=0.05$ level of prob- 
ability. Significant pasture treatment $\times$ rotation interactions were plotted, using the interaction means and standard error of the mean, and examined for patterns. For herbage intake analyses, the TMR treatment was included as an additional experimental unit.

Multivariate analyses were conducted to determine which physical and chemical herbage characteristics were primarily associated with differences in herbage intake following the procedures outlined by Yeater and Villamil (2017). All multivariate analyses were performed using R v3.6.1 (https://www.r-project.org/) and the R packages MASS (Venables and Ripley, 2002) and FACTOEXTRA (Kassambara and Mundt, 2020). First, as collinearity was expected among the 18 measured herbage characteristics, a principal component analysis (PCA) was performed using the correlation matrix (e.g., to account for different units of measure) with the princomp() function. Second, multiple regression was conducted on measures of herbage intake versus the first 4 principal components (PC; e.g., those with a eigenvalue greater than 1.0) using the $\operatorname{lm}()$ function. Third, canonical discriminant analysis using the linear discriminants from the first $3 \mathrm{PC}$ was conducted using the $l d a()$ and predict () functions to determine ability of our herbage characteristics model to discriminate among the predefined pasture treatments. Fourth, PCA biplots were created using the fviz_pca_var() function to examine relationships among herbage characteristics. Finally, the herbage characteristics that contributed most to each PC were identified by examining absolute loading scores (e.g., mostly $>0.3$; Yeater and Villamil, 2017) and as a function of loading scores and PC standard deviations (Kassambara and Mundt, 2020). These contributing herbage characteristics were considered to be largely explanatory of the variation in herbage intake and used for further discussion.

\section{RESULTS}

\section{Herbage Intake and Trait Differences}

Pasture type (e.g., average of mixture vs. monoculture), pasture treatment, and rotation all had a significant $(P<0.001)$ effect on the amount of herbage intake by grazing Jersey heifers. Pasture treatment interactions with rotation were also significant $(P=0.001-0.015$, Table 1), primarily due to herbage intake decreasing from rotation 1 to 2 and then rebounding in rotation 3 . However, PR and PR+BFT were exceptions as herbage intake did not recover in rotation 3 (Supplemental Figure S1, https://doi.org/10.6084/m9.figshare.16441266.v1, Waldron, 2021). On average, herbage intake of mixture pastures was greater $(P<0.05)$ than monocultures
(Table 1$)$. Herbage intake was also greater $(P<0.05)$ in rotation 3 than rotations 1 and 2 (Table 1 ), but herbage mass did not limit herbage intake, with only 22 to $47 \%$ of herbage used (treatment $\times$ rotation basis; data not shown). Individual pasture treatments also differed, with the $\mathrm{PR}+\mathrm{BFT}, \mathrm{MB}+\mathrm{BFT}$, and $\mathrm{OG}+\mathrm{BFT}$ pastures exhibiting the greatest $(P<0.05)$ herbage intake, whereas PR had the least herbage intake (Table 1). Grass-binary mixtures with BFT consistently increased $(P<0.05)$ herbage intake for all grasses, compared with their respective monocultures (Table 1; Supplemental Figure S1). Apparent herbage intake of heifers consuming TMR was greater $(P<0.05)$ than pasture treatments and in close agreement with predicted herbage intake (based upon TMR nutritive value; Table 1). In contrast, herbage intake of pasture treatments was somewhat less than predicted, especially for the PR treatment (Table 1).

Details on the effects of pastures on the measured herbage characteristics are given in Tables 2, 3, 4, and 5 . In brief, most main effects were significant $(P<$ $0.05)$, with the exception of pasture type on IVTD. As expected, pasture treatments exhibited a wide range $(P$ $<0.05$ ) of pre- and postgrazing herbage height, herbage mass, and daily herbage accumulation (Table 2). These herbage characteristics were the basis of calculating estimates of herbage intake and herbage allowance, and thus not included in multivariate analyses. Pasture treatment $\times$ rotation interactions were also significant $(P=0.001$ to 0.013$)$ for physical characteristics of herbage mass, herbage allowance and herbage height, and all nutritive value measures. Most of these interactions were changes in magnitude from rotation to rotation, and rarely involved major rank change among pasture treatments. Therefore, herein, the results are primarily presented as the means of the main effects. However, treatment $\times$ rotation interactions of highly-explanatory herbage characteristics were also explored by plotting interaction means and presented as supplementary material (Supplemental Figures S1S4, https://doi.org/10.6084/m9.figshare.16441266.v1, Waldron, 2021). On average, mixtures had greater $(P<$ 0.001 ) herbage allowance, herbage height, $\mathrm{CP}, \mathrm{NFC}$, and $\mathrm{ME}$, and more favorable (i.e., lesser; $P<0.001$ ) NDF and ADF, but less $(P<0.001)$ favorable ADL, NDFD, WSC, and fatty acids than grass monocultures (Tables $3,4$, and 5$)$. The effect of individual pasture treatments was also significant $(P<0.001)$ for all herbage characteristics, with individual grass + BFT mixtures differing $(P<0.05)$ from their respective grass monocultures for all physical characteristics, and $\mathrm{CP}, \mathrm{NDF}, \mathrm{ADF}, \mathrm{ADL}$, fructans, and ME (Tables 3-5). Metabolizable energy results confirmed that chosen grass entries exhibited a 
Table 1. Measures of estimated grazing efficiency (GE) and apparent- and predicted-herbage intake by Jersey heifers (HF) from a grazing study in Lewiston, Utah, in 2017 and $2018^{1}$

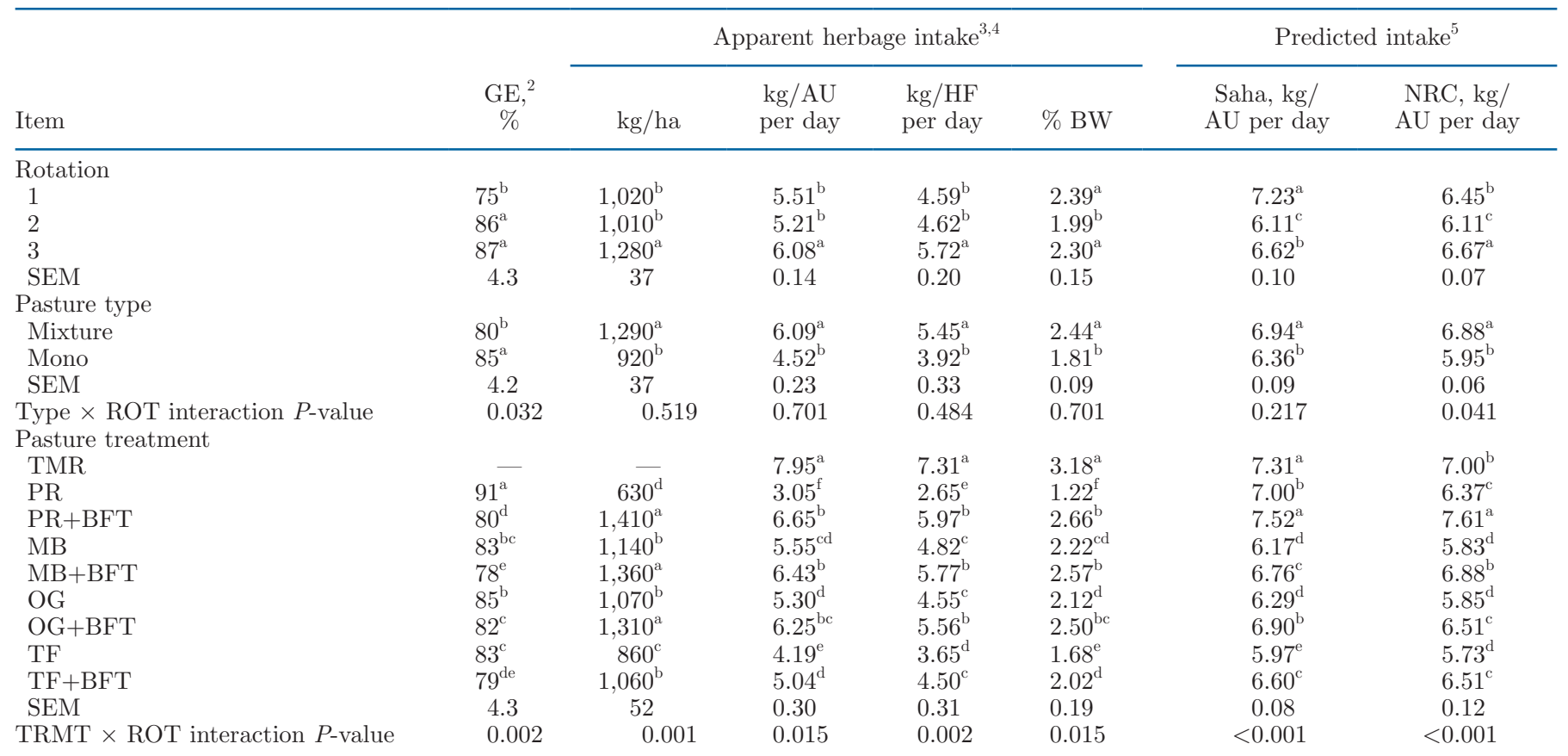

${ }^{\mathrm{a}-\mathrm{f}}$ Mean values within columns of rotation, treatment type, or pasture treatment with different superscripts are significantly different $(P=0.05)$. ${ }^{1}$ The main effects and interactions among rotation (ROT), pasture type (Type), and pasture treatment (TRMT) for these herbage characteristics are shown. Pasture treatments included monocultures of meadow brome (MB), orchardgrass (OG), perennial ryegrass (PR), tall fescue (TF), and each grass in a binary mixture with birdsfoot trefoil (BFT).

${ }^{2}$ Grazing efficiency, defined as the proportion of herbage consumed by livestock compared with the total that disappears due to all activities, was estimated as a function of herbage allowance.

${ }^{3}$ Apparent herbage intake measured as the disappearance of herbage mass as determined via a calibrated rising plate meter at pre- and postgrazing of 7-d grazing periods. Estimated herbage accumulation during the 7-d grazing period and GE included in estimates.

${ }^{4}$ The number and BW of HF in each paddock were recorded and converted to animal units (AU) where 1 AU = a 250-kg Jersey HF (Allen et al., 2011).

${ }^{5}$ Predicted herbage intake calculated using a weighted average of the grass and legume DMI equations in Saha et al. (2010) and the all-forage diet DMI equation for growing cattle in NRC (2000)

range of inherent dietary energy with PR being greatest, OG and MB intermediate, and TF the least $(P<$ 0.05 ; Table 3 ).

\section{Explanatory Herbage Characteristics}

The first 4 PC from PCA of all measured herbage variables explained $38,27,19$, and $6 \%$ of the variation found in the data, respectively (i.e., $90 \%$ cumulatively). Multiple regression on these $4 \mathrm{PC}$ resulted in significant models $(P<0.001)$ with all $\mathrm{PC}$ contributing to the model $(P<0.001)$, and $\mathrm{R}^{2}$ values of 0.53 , 0.51 , and 0.53 for measures of apparent herbage intake of kilograms per hectare, kilograms per AU per day, and kilograms per heifer per day, respectively. Canonical discriminant analysis resulted in the first 3 linear discriminants explaining 75,19 , and $6 \%$ of the variation between the pre-defined pasture treatments, respectively (100\% cumulatively). Furthermore, the first linear discriminant was primarily influenced by PC1 and PC2 as determined by coefficients. However, cross-validation determined that the accuracy of discriminating among pasture treatments was on average only $58 \%$, with the $\mathrm{PR}$ and $\mathrm{PR}+\mathrm{BFT}$ treatment most likely to be characterized $(89 \%)$ and the MB treatment least characterized (22\%; Supplemental Table S1, https://doi.org/10.6084/m9.figshare.16441266.v1, Waldron, 2021).

The first PC included all but 3 of the 16 herbage characteristics, but NDF, ADF, NFC, ME, IVTD, and WSC contributed the most to this PC (Figure 2). Principal component 1 showed a contrast between NDF and ADF on one hand, and NFC, ME, IVTD, and WSC on the other, indicative that the pasture treatments mainly differed in their digestibility and resulting energy (Figure 2). On average, PR+BFT had the least (most favorable; $P<0.05$ ) ADF and NDF, followed closely by PR, whereas NDF was greatest $(P<0.05)$ in 
Table 2. Herbage height, mass, and accumulation of pasture treatments in a Jersey heifer grazing study conducted in Lewiston, Utah, in 2017 and $2018^{1}$

\begin{tabular}{|c|c|c|c|c|c|}
\hline Item & $\begin{array}{c}\text { Pre-HT, }{ }^{2} \\
\text { cm }\end{array}$ & $\begin{array}{c}\text { Post-HT, } \\
\mathrm{cm}\end{array}$ & $\begin{array}{c}\text { Pre-MASS, } \\
\text { kg/ha }\end{array}$ & $\begin{array}{c}\text { Post-MASS, } \\
\text { kg/ha }\end{array}$ & $\begin{array}{c}\text { DHA, } \\
\mathrm{kg} / \mathrm{ha} \text { per day }\end{array}$ \\
\hline \multicolumn{6}{|l|}{ Rotation } \\
\hline 1 & $42.3^{\mathrm{a}}$ & $29.9^{\mathrm{a}}$ & $3,400^{\mathrm{a}}$ & $2,400^{\mathrm{a}}$ & $55.8^{\mathrm{b}}$ \\
\hline 3 & $33.2^{\mathrm{b}}$ & $19.9^{\mathrm{c}}$ & $2,640^{\mathrm{b}}$ & $1,580^{\mathrm{c}}$ & $61.6^{\mathrm{a}}$ \\
\hline SEM & 0.56 & 0.81 & 313 & 227 & 3.6 \\
\hline \multicolumn{6}{|l|}{ Pasture type ${ }^{3}$} \\
\hline Type $\times$ ROT $P$-value & 0.527 & 0.620 & 0.144 & 0.166 & 0.896 \\
\hline \multicolumn{6}{|l|}{ Pasture treatment } \\
\hline PR & $24.5^{\mathrm{d}}$ & $17.4^{\mathrm{g}}$ & $1,760^{\mathrm{e}}$ & $1,250^{\mathrm{f}}$ & $27.4^{\mathrm{d}}$ \\
\hline $\mathrm{PR}+\mathrm{BFT}$ & $32.0^{\mathrm{c}}$ & $19.6^{\mathrm{f}}$ & $3,370^{\mathrm{a}}$ & $2,070^{\mathrm{b}}$ & $69.9^{\mathrm{a}}$ \\
\hline $\mathrm{MB}$ & $35.3^{\mathrm{b}}$ & $22.7^{\mathrm{e}}$ & $2,750^{\mathrm{c}}$ & $1,770^{\mathrm{d}}$ & $55.1^{\mathrm{c}}$ \\
\hline $\mathrm{MB}+\mathrm{BFT}$ & $40.2^{\mathrm{a}}$ & $25.8^{\mathrm{bc}}$ & $3,510^{\mathrm{a}}$ & $2,260^{\mathrm{a}}$ & $70.8^{\mathrm{a}}$ \\
\hline TRMT $\times$ ROT $P$-value & 0.002 & $<0.001$ & 0.013 & $<0.001$ & $<0.001$ \\
\hline
\end{tabular}

${ }^{\mathrm{a}-\mathrm{g}}$ Mean values within columns of rotation, treatment type, or pasture treatment with different superscripts are significantly different $(P=0.05)$.

${ }^{1}$ The main effects and interactions among rotation (ROT), pasture type (Type), and pasture treatment (TRMT) for these herbage characteristics are shown. Pasture treatments included monocultures of meadow brome (MB), orchardgrass (OG), perennial ryegrass (PR) and tall fescue (TF), and each grass in a binary mixture with birdsfoot trefoil (BFT).

${ }^{2}$ Compressed height pre-grazing and following a 7-d grazing period (Pre-HT and Post-HT, respectively), herbage mass pre-grazing and following a 7-d grazing period (Pre-MASS and Post-MASS, respectively), and estimated daily herbage accumulation as calculated from herbage growth during 28-d rest period between grazing rotation cycles (DHA).

${ }^{3}$ For pasture type and pasture treatment, values represent the mean of three 35 -d rotations.

$\mathrm{MB}$ and $\mathrm{ADF}$ greatest in MB and $\mathrm{OG}$ (Table 3). The $\mathrm{PR}$ and $\mathrm{PR}+\mathrm{BFT}$ treatments exhibited the greatest $(P$ $<0.05)$ concentrations of NFC and WSC, validating the claim of it being a high-sugar perennial ryegrass cultivar, whereas these carbohydrate fractions in the putative high-sugar $\mathrm{OG}$ and $\mathrm{OG}+\mathrm{BFT}$ were the least (i.e., NFC; $P<0.05$ ) or not different (i.e., WSC) compared with the remaining pasture treatments (Table 3). Metabolizable energy followed a similar pattern as carbohydrate concentrations; however, $\mathrm{ME}$ in $\mathrm{MB}+\mathrm{BFT}$ and $\mathrm{OG}+\mathrm{BFT}$ were equivalent to $\mathrm{PR}$ and $\mathrm{PR}+\mathrm{BFT}$ in rotations 2 and 3 (Supplemental Figure S2, https://doi. org/10.6084/m9.figshare.16441266.v1, Waldron, 2021).

The second PC showed a contrast between percent of $\mathrm{BFT}$, percent of $\mathrm{CT}$ in herbage, $\mathrm{CP}$, and ADL versus NDFD, suggesting that the variation explained by this $\mathrm{PC}$ was primarily related to the amount of BFT in the herbage (Figure 2). On average, PR had the greatest $(P<0.05)$ NDFD and least $(P<0.05)$ ADL (e.g., most favorable values), whereas $\mathrm{PR}+\mathrm{BFT}$ had the least favorable levels of both these characteristics, corresponding to the greatest $(P<0.05)$ BFT proportion (Table 4; Supplemental Figures S1, S3, and S4, https:/ / doi.org/10.6084/m9.figshare.16441266.v1, Waldron, 2021). Similarly, CP was greater $(P<0.05)$ in all grass-
BFT mixtures than their respective monocultures. A notable pasture treatment $\times$ rotation interaction resulted from PR+BFT in which NDFD decreased, and $\mathrm{ADL}$, percent of BFT, and percent of $\mathrm{CT}$ in herbage increased between rotations 2 and 3 , in contrast to the other treatments (Supplemental Figure S4, https://doi. org/10.6084/m9.figshare.16441266.v1, Waldron, 2021).

The third PC included explanatory variables of herbage allowance, herbage height, and fructan, and grouped herbage allowance and herbage height versus fructan, somewhat suggesting an herbage mass effect (Figure 3). Herbage allowance and herbage height both decreased from rotation 1 to 2 but very little from rotation 2 to 3 (e.g., treatment $\times$ rotation interaction significance of $P=0.002)$. This herbage allowance decrease was more so for MB, TF, and OG and their mixtures than the shorter statured PR and PR+BFT (data not shown). Overall, herbage allowance was greatest $(P<0.05)$ for $\mathrm{MB}+\mathrm{BFT}$ and $\mathrm{TF}+\mathrm{BFT}$, and approximately double the least found in PR. The fourth PC only explained $6 \%$ of the variation among treatments, with the primary explanatory characteristic of fatty acids (Figure $3)$. With the exception of TF and TF+BFT, monocultures had greater $(P<0.05)$ fatty acids than respective mixtures (Table 5). 
Table 3. Measures of herbage characteristics ${ }^{1}$ of pasture treatments in a Jersey heifer grazing study conducted in Lewiston, Utah, in 2017 and $2018^{2}$

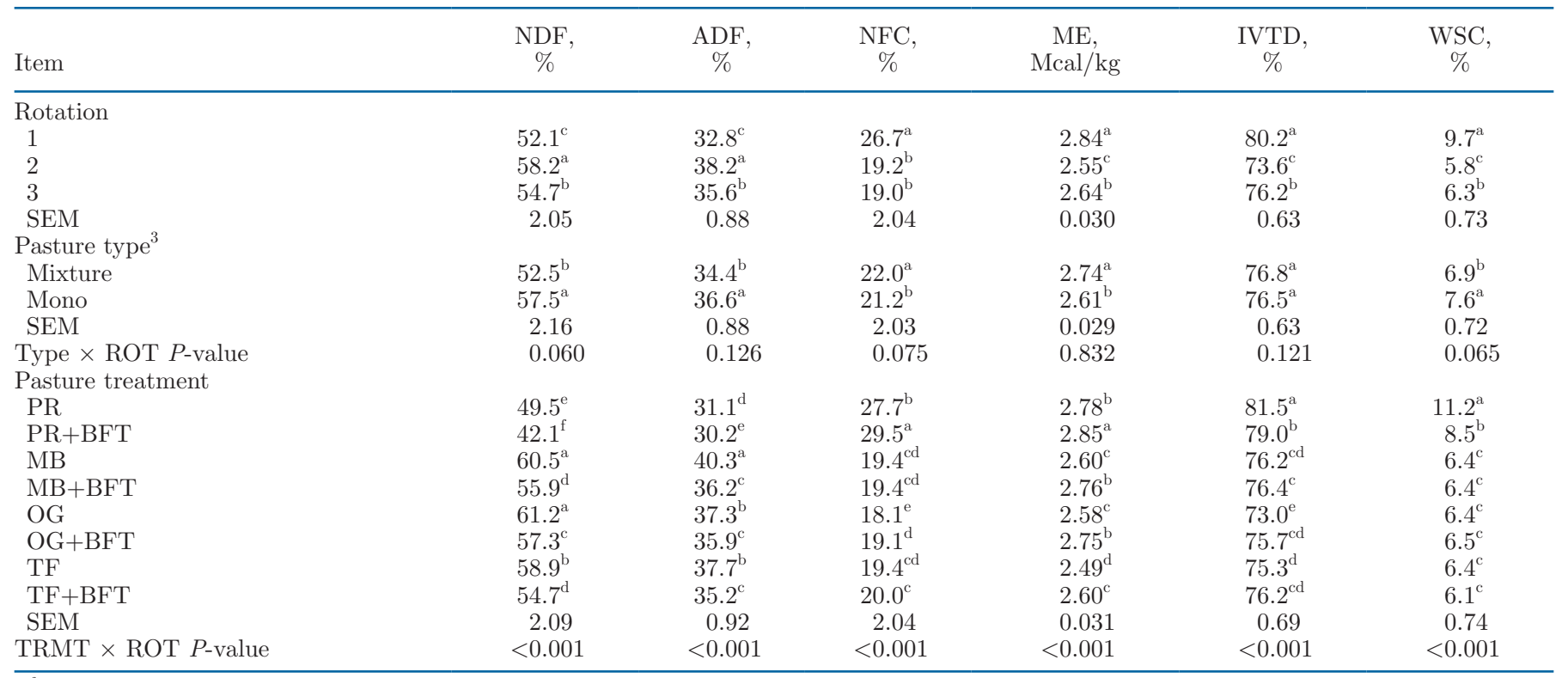

${ }^{\mathrm{a}-\mathrm{f}}$ Mean values within columns of rotation, treatment type, or pasture treatment with different superscripts are significantly different $(P=0.05)$. ${ }^{1}$ IVTD $=$ in vitro true digestibility; WSC $=$ water-soluble carbohydrates.

${ }^{2}$ These characteristics were identified as contributing the most to principal component (PC) 1 following PC analysis of the variation among pasture treatments (PC1 explained $38 \%$ of variation). The main effects and interactions among rotation (ROT), pasture type (Type), and pasture treatment (TRMT) for these herbage characteristics are shown. Pasture treatments included monocultures of meadow brome (MB), orchardgrass $(\mathrm{OG})$, perennial ryegrass $(\mathrm{PR})$ and tall fescue $(\mathrm{TF})$, and each grass in a binary mixture with birdsfoot trefoil (BFT).

${ }^{3}$ For pasture type and pasture treatment, values represent the mean of three 35-d rotations.

\section{DISCUSSION}

\section{Herbage Intake Differences}

Pasture-based milk production is the fastest growing segment of US organic agriculture, but such dairies experience up to $32 \%$ decrease in milk production (McBride and Greene, 2009) due to reduced DMI by grazing dairy cows (Bargo et al., 2003). Thus, characterizing pasture herbage characteristics that are associated with herbage intake is useful in identifying the optimum pasture mixtures. In this study, we observed variation among pasture treatments in both herbage intake, as well as in herbage quantity and quality. On average, grass-BFT mixtures had greater $(P<0.05)$ herbage intake than grass monocultures (6.1 and 4.5 $\mathrm{kg} / \mathrm{AU}$ per day, respectively), but both were less than heifers consuming TMR (7.9 kg/AU per day; Table 1$)$. These levels of apparent herbage intake equate to 2.4 and $1.8 \%$ of heifer BW for grass-BFT mixtures and grass monocultures, respectively, with the monoculture herbage intake considerably less than norms (e.g., 2.6\% BW) for growing cattle within this weight class consuming a diet with similar ME (NRC, 2000). The 2 measures of predicted herbage intake are for all-forage diets, and for the most part in agreement with each other [Pearson correlation $\left(\mathrm{r}_{\mathrm{P}}\right)$ of 0.92 and Spearman's rank correlation $\left(\mathrm{r}_{\mathrm{S}}\right)$ of 0.83$]$. In contrast, there was a discrepancy between measured and predicted herbage intake $(\mathrm{kg} /$ AU per day; $r_{P}=0.32$ and 0.54, for Saha and NRC estimates, respectively; Table 1), suggesting our herbage intake estimates may have been low. Although pasture intake is expected to be less than TMR intake (Bargo et al., 2003), our lesser values could also be reflective of the difficulties of measuring pasture intake using the disappearance method. As such, one possible explanation could be unaccounted herbage accumulation (e.g., growth and regrowth) during the 7-d grazing period. However, our estimated herbage accumulation rates of 55 and $51 \mathrm{~kg} / \mathrm{ha}$ per day align with previous reports of fescue and orchardgrass regrowth rates of 20 to $60 \mathrm{~kg} /$ ha per day (Belesky and Fedders, 1994; Bonesmo and Skjelvåg, 1999), suggesting that our model sufficiently accounts for regrowth. The most notable difference between observed and predicted herbage intake was in PR. This might suggest that the rising plate meter was less effective at measuring disappearance of PR, which is lower in stature and more closely grazed by livestock than the other grass species (e.g., as previously noted we reduced stubble height for clipped samples between 
years based upon these observations). However, the methodology of separate rising plate meter prediction equations for each treatment-year combination and resulting regression $\mathrm{R}^{2}$ of 0.81 and 0.85 for $\mathrm{PR}$ in 2017 and 2018, respectively, indicate this was not the case. Overall, we concluded that our apparent intake measures of pasture were mostly reasonable estimates of actual herbage intake and provided reliable relative comparisons among pasture treatments; interpretation of results of the PR treatment requires some caution.

The greater herbage intake of grass-BFT mixtures compared with grass monocultures coincides with previous studies that have concluded that legumes increase forage intake. For instance, Woodward et al. (2000) found that cows fed freshly harvested BFT in a feed bunk had increased forage intake compared with cows fed freshly cut PR, and MacAdam et al. (2015) reported that dairy cows grazing BFT monocultures had greater herbage intake than those grazing grass monocultures. Ribeiro Filho et al. (2003, 2005) found that grass-clover swards with clover contents of $42 \%$ increased herbage intake over the grass monocultures, but swards with $27 \%$ clover did not $(P>0.05)$. In contrast, our BFT proportion ranged from 14 to $41 \%$ of herbage (Table 1 ) and significantly increased $(P<0.05)$ herbage intake by 0.85 to $3.60 \mathrm{~kg} / \mathrm{AU}$ per day over respective grass monocultures, regardless of BFT percentage.

It is often difficult to obtain significant differences in grazing studies given the limited replication and high spatial and biological variability of pastures and cattle (Bransby, 1989, Giesbrecht, 1989). However, multivariate analysis uses correlated variables, such as herbage characteristics, and given the response data, can point to which variables drive even subtle differences among the treatments (Yeater and Villamil, 2017). As such, multiple regression using the first 4 principal components from PCA explained up to $53 \%$ of the variation in herbage intake by the Jersey heifers, with the most explanatory herbage characteristics corresponding to fiber and energy (PC1) and BFT-related characteristics (PC2). The inability of our models to explain $100 \%$ of the variation indicated that there were unidentified variables associated with herbage intake, possibly including environmental conditions, heifer breeding and background, and measuring errors. Nevertheless, we found differences $(P<0.001)$ among pasture treatments for herbage intake, and the moderately high $\mathrm{R}^{2}$ of $53 \%$ and $58 \%$ from PCA-regression and canonical

Table 4. Measures of herbage characteristics ${ }^{1}$ of pasture treatments in a Jersey heifer grazing study conducted in Lewiston, Utah, in 2017 and 2018

\begin{tabular}{|c|c|c|c|c|c|c|}
\hline Item & $\underset{\%}{\text { BFTPERC, }}$ & $\underset{\%}{\text { BFTCT, }}$ & $\underset{\%}{\operatorname{HERBCT},}$ & $\begin{array}{c}\mathrm{CP}, \\
\%\end{array}$ & $\underset{\%}{\mathrm{ADL}}$ & $\begin{array}{l}\text { NDFD, } \\
\% \mathrm{NDF}\end{array}$ \\
\hline \multicolumn{7}{|l|}{ Rotation } \\
\hline 1 & $14.6^{\mathrm{b}}$ & $0.81^{\mathrm{b}}$ & $0.14^{\mathrm{c}}$ & $11.8^{\mathrm{b}}$ & $3.9^{\mathrm{c}}$ & $64.3^{\mathrm{a}}$ \\
\hline 3 & $27.7^{\mathrm{a}}$ & $1.35^{\mathrm{a}}$ & $0.35^{\mathrm{a}}$ & $13.9^{\mathrm{a}}$ & $4.0^{\mathrm{b}}$ & $59.6^{\mathrm{b}}$ \\
\hline SEM & 7.1 & 0.08 & 0.06 & 0.20 & 0.07 & 0.40 \\
\hline \multicolumn{7}{|l|}{ Pasture type $^{2}$} \\
\hline Type $\times$ ROT $P$-value & & & & 0.043 & 0.001 & 0.203 \\
\hline \multicolumn{7}{|l|}{ Pasture treatment } \\
\hline $\mathrm{PR}$ & - & - & - & $10.8^{\mathrm{d}}$ & $3.3^{\mathrm{f}}$ & $66.2^{\mathrm{a}}$ \\
\hline $\mathrm{PR}+\mathrm{BFT}$ & $41.0^{\mathrm{a}}$ & $1.25^{\mathrm{a}}$ & $0.48^{\mathrm{a}}$ & $17.6^{\mathrm{a}}$ & $5.4^{\mathrm{a}}$ & $55.4^{\mathrm{d}}$ \\
\hline $\mathrm{MB}$ & - & - & - & $10.5^{\mathrm{de}}$ & $3.8^{\mathrm{e}}$ & $60.6^{\mathrm{b}}$ \\
\hline $\mathrm{MB}+\mathrm{BFT}$ & $20.7^{\mathrm{b}}$ & $1.10^{\mathrm{ab}}$ & $0.22^{\mathrm{b}}$ & $15.3^{\mathrm{b}}$ & $4.4^{\mathrm{b}}$ & $59.9^{\mathrm{b}}$ \\
\hline TRMT $\times$ ROT $P$-value & 0.145 & 0.336 & 0.001 & $<0.001$ & $<0.001$ & $<0.001$ \\
\hline
\end{tabular}

${ }^{\mathrm{a}-\mathrm{f}}$ Mean values within columns of rotation, treatment type, or pasture treatment with different superscripts are significantly different $(P=0.05)$. ${ }^{1}$ BFTPERC $=$ proportion of birdsfoot trefoil in herbage; BFTCT $=$ percent condensed tannin in the birdsfoot trefoil; HERBCT $=$ percent condensed tannin in the total (i.e., grass+BFT) herbage; and neutral detergent fiber digestibility (NDFD). These characteristics were identified as contributing the most to principal component (PC) 2 following $\mathrm{PC}$ analysis of the variation among pasture treatments (PC2 explained $27 \%$ of variation). The main effects and interactions among rotation (ROT), pasture type (Type), and pasture treatment (TRMT) for these herbage characteristics are shown. Pasture treatments included monocultures of meadow brome (MB), orchardgrass (OG), perennial ryegrass (PR) and tall fescue (TF), and each grass in a binary mixture with birdsfoot trefoil (BFT).

${ }^{2}$ For pasture type and pasture treatment, values represent the mean of three 35 -d rotations. 
Table 5. Measures of herbage characteristics ${ }^{1}$ of pasture treatments in a Jersey heifer grazing study conducted in Lewiston, Utah, in 2017 and 2018

\begin{tabular}{|c|c|c|c|c|}
\hline \multirow[b]{2}{*}{ Item } & \multicolumn{3}{|c|}{ PC3 } & \multirow{2}{*}{$\frac{\mathrm{PC} 4}{\underset{\%}{\mathrm{FA}}}$} \\
\hline & $\begin{array}{c}\mathrm{HA}, \\
\mathrm{kg} / \mathrm{kg} \mathrm{BW}\end{array}$ & $\begin{array}{l}\mathrm{HT}, \\
\mathrm{cm}\end{array}$ & $\begin{array}{c}\text { Fructan, } \\
\%\end{array}$ & \\
\hline \multicolumn{5}{|l|}{ Rotation } \\
\hline 1 & $2.27^{\mathrm{a}}$ & $36.1^{\mathrm{a}}$ & $1.21^{\mathrm{c}}$ & $2.33^{\mathrm{c}}$ \\
\hline 2 & $1.50^{\mathrm{b}}$ & $26.3^{\mathrm{b}}$ & $1.50^{\mathrm{b}}$ & $2.39^{\mathrm{b}}$ \\
\hline 3 & $1.40^{\mathrm{b}}$ & $26.5^{\mathrm{b}}$ & $1.64^{\mathrm{a}}$ & $2.81^{\mathrm{a}}$ \\
\hline SEM & 0.325 & 0.71 & 0.047 & 0.030 \\
\hline \multicolumn{5}{|l|}{ Pasture type ${ }^{2}$} \\
\hline Mixture & $1.93^{\mathrm{a}}$ & $31.4^{\mathrm{a}}$ & $1.46^{\mathrm{a}}$ & $2.35^{\mathrm{b}}$ \\
\hline Mono & $1.51^{\mathrm{b}}$ & $27.9^{\mathrm{b}}$ & $1.44^{\mathrm{b}}$ & $2.67^{\mathrm{a}}$ \\
\hline SEM & 0.324 & 0.55 & 0.045 & 0.035 \\
\hline Type $\times$ ROT $P$-value & 0.032 & 0.571 & 0.598 & 0.030 \\
\hline \multicolumn{5}{|l|}{ Pasture treatment } \\
\hline $\mathrm{PR}$ & $1.10^{\mathrm{e}}$ & $21.0^{\mathrm{e}}$ & $1.77^{\mathrm{a}}$ & $2.86^{\mathrm{b}}$ \\
\hline $\mathrm{PR}+\mathrm{BFT}$ & $1.93^{\mathrm{b}}$ & $25.8^{\mathrm{d}}$ & $1.70^{\mathrm{b}}$ & $2.12^{\mathrm{g}}$ \\
\hline MB & $1.68^{\mathrm{cd}}$ & $29.0^{\mathrm{c}}$ & $1.31^{\mathrm{f}}$ & $2.54^{\mathrm{d}}$ \\
\hline $\mathrm{MB}+\mathrm{BFT}$ & $2.07^{\mathrm{a}}$ & $33.1^{\mathrm{ab}}$ & $1.36^{\mathrm{d}}$ & $2.35^{\mathrm{e}}$ \\
\hline $\mathrm{OG}$ & $1.56^{\mathrm{d}}$ & $29.9^{\mathrm{c}}$ & $1.35^{\mathrm{de}}$ & $3.03^{\mathrm{a}}$ \\
\hline $\mathrm{OG}+\mathrm{BFT}$ & $1.74^{\mathrm{c}}$ & $32.3^{\mathrm{b}}$ & $1.43^{\mathrm{c}}$ & $2.73^{\mathrm{c}}$ \\
\hline $\mathrm{TF}$ & $1.70^{\mathrm{c}}$ & $31.9^{\mathrm{b}}$ & $1.32^{\mathrm{ef}}$ & $2.27^{\mathrm{ef}}$ \\
\hline $\mathrm{TF}+\mathrm{BFT}$ & $1.99^{\mathrm{ab}}$ & $34.4^{\mathrm{a}}$ & $1.36^{\mathrm{d}}$ & $2.19^{\mathrm{fg}}$ \\
\hline SEM & 0.327 & 0.72 & 0.046 & 0.045 \\
\hline TRMT $\times$ ROT $P$-value & 0.002 & 0.001 & $<0.001$ & $<0.001$ \\
\hline
\end{tabular}

${ }^{\mathrm{a}-\mathrm{g}}$ Mean values within columns of rotation, treatment type, or pasture treatment with different superscripts are significantly different $(P=0.05)$.

${ }^{1} \mathrm{FA}=$ fatty acids; $\mathrm{HA}=$ herbage allowance; $\mathrm{HT}=$ pre-grazing compressed height $(\mathrm{HT})$. These characteristics were identified as contributing the most to principal components (PC) 3 and 4 following PC analysis of the variation among pasture treatments (PC3 and PC4 explained 19 and $6 \%$ of variation, respectively). The main effects and interactions among rotation (ROT), pasture type (Type), and pasture treatment (TRMT) for these herbage characteristics are shown. Pasture treatments included monocultures of meadow brome (MB), orchardgrass $(\mathrm{OG})$, perennial ryegrass $(\mathrm{PR})$ and tall fescue $(\mathrm{TF})$, and each grass in a binary mixture with birdsfoot trefoil (BFT).

${ }^{2}$ For pasture type and pasture treatment, values represent the mean of three 35 -d rotations.

discriminant analysis, respectively, indicated that herbage intake differences were associated with the variation in herbage.

\section{Herbage Characteristics Associated With Differences in Pastures and Herbage Intake}

Fiber and Energy (PC1). Fiber in forage diets has been reported to be the single best nutritive predictor of forage intake (Waldo, 1986) and is the main source of energy for ruminants (Wilson, 1994). As such, it is not surprising that fiber concentrations, digestibility, and energy contributed the most to PC1, indicative of their importance in explaining the differences among pasture treatments. Although it has been proposed that NDF intake of lactating dairy cattle on mixed rations will not exceed $1.3 \%$ of $\mathrm{BW}$, research indicates that animals on pastures with high herbage allowance often consume greater than $1.3 \%$ NDF (Vazquez and Smith, 2000). In this study, herbage allowance greatly exceeded metabolic need (e.g., $\sim 2.0-2.5 \%$ of BW) and average apparent NDF intake was 1.0 and $1.3 \%$ of BW for grass monocultures and BFT mixtures, respectively (based upon herbage intake and NDF estimates). However, the $\mathrm{MB}+\mathrm{BFT}$ and $\mathrm{OG}+\mathrm{BFT}$ treatments exhibited the greatest apparent NDF intake at $1.4 \%$ BW, but were the most consumed pasture treatments along with PR+BFT. Fiber constituents such as NDF are highly variable and influenced by multiple factors including plant maturity. Yet, the relative differences observed among pastures were consistent with previous geographically close studies for orchardgrass (51-61\% NDF; Robins et al., 2015, 2016) and TF (50-55\% NDF; Waldron et al., 2020). Thus, this among-study relative consistency for species-inherent NDF may help explain why the NDF component was of such explanatory importance in multivariate and regression analyses.

Total dietary energy (i.e., ME), nonstructural carbohydrates (NSC; i.e., NFC and WSC), and digestibility (i.e., IVTD) were the other predominate explanatory variables in $\mathrm{PC} 1$. On average, grass-BFT mixture $\mathrm{ME}$ was greater $(P<0.05)$ than that of grass monoculture, and every individual grass-BFT pasture ME was greater $(P<0.05)$ than its corresponding grass monoculture. 
Given these differences, and the fact that energy is often the most limiting nutrient on pasture (Kolver and Muller, 1998; Bargo et al., 2003), it is not surprising that ME was associated with pasture treatment and herbage intake differences. Nonfiber carbohydrates were closely correlated with ME (Figure 2), with the PR+BFT and $\mathrm{OG}+\mathrm{BFT}$ treatments having greater $(P<0.05)$ NFC than their respective monocultures. Interestingly, multiple authors have concluded that feeding high NFC supplements to grazing animals reduced intake of pasture, which they attributed to reduced ruminal $\mathrm{pH}$ and a lower rate of fiber digestion (Vazquez and Smith, 2000; Baudracco et al., 2010). However, Stakelum and Dillon (2003) found that supplementing with fibrous concentrates had a less depressing effect on grass intake than cereal (starchy) based concentrates, possibly helping to explain our results.

Multiple authors have indicated that grasses with increased WSC have more efficient digestibility and increased ME levels (Miller et al., 2001; Edwards et al., 2007; Smith et al., 2007; Waghorn, 2007). We also found that digestibility and WSC were highly correlated with each other and also with ME (Figure 2).

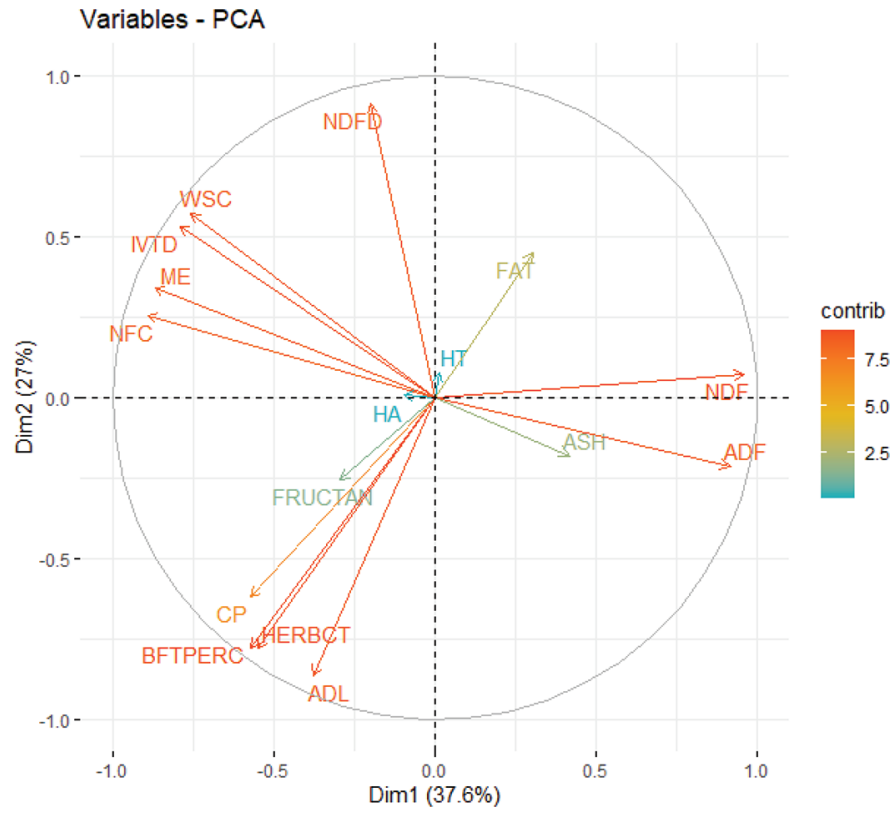

Figure 2. Principal components analysis (PCA) biplot of principal components (PC) 1 versus 2 (Dim1 and Dim2, respectively) from analysis of the physical and chemical herbage characteristics inherent to the pasture species of a Jersey heifer grazing study in Lewiston, Utah, in 2017 and 2018. Contribution of each trait to the PC (i.e., labeled "contrib") as a proportion of $100 \%$ is shown. Herbage trait abbreviations: proportion of birdsfoot trefoil in herbage (BFTPERC), herbage allowance (HA), percent condensed tannin in the total (i.e., grass+BFT) herbage (HERBCT), compressed height (HT), in vitro true digestibility (IVTD), NDF digestibility (NDFD), and water-soluble carbohydrates (WSC).

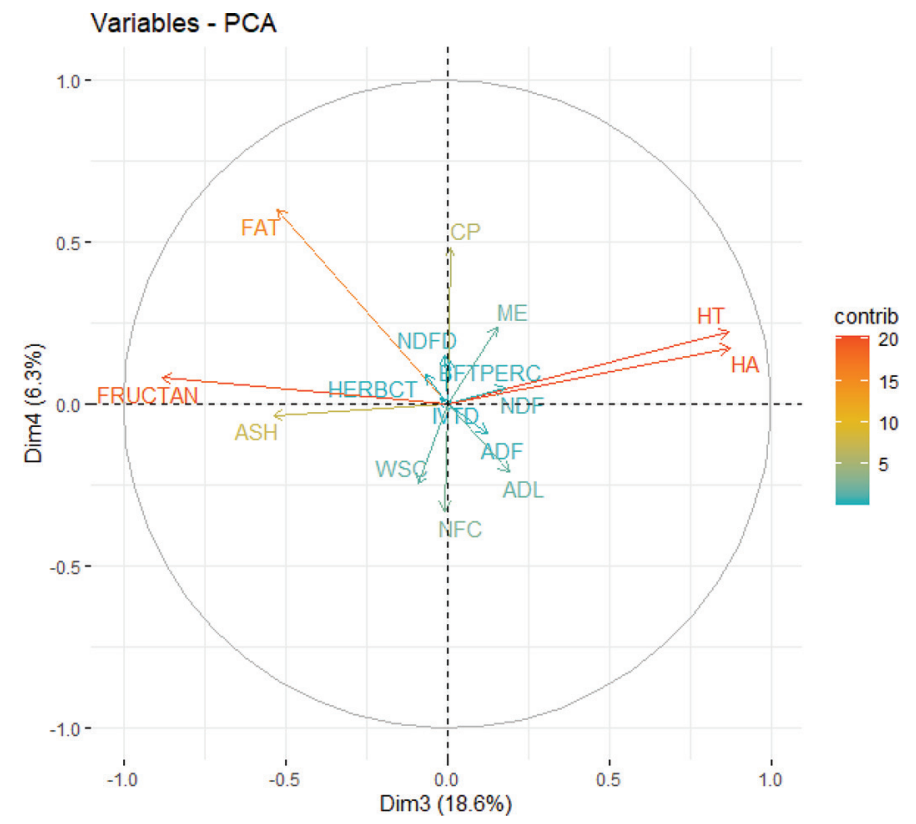

Figure 3. Principal component analysis (PCA) biplot of principal components (PC) 3 versus PC 4 (Dim3 and Dim4, respectively) from analysis of the physical and chemical herbage characteristics inherent to the pasture species of a Jersey heifer grazing study in Lewiston, Utah, in 2017 and 2018. Contribution of each trait to the PC (i.e., labeled "contrib") as a proportion of $100 \%$ is shown. Herbage trait abbreviations: proportion of birdsfoot trefoil in herbage (BFTPERC), herbage allowance (HA), percent condensed tannin in the total (i.e., grass+BFT) herbage (HERBCT), compressed height (HT), in vitro true digestibility (IVTD), NDF digestibility (NDFD), and water-soluble carbohydrates (WSC).

Mayland et al. (2000) examined the effect that different types of NSC have on animal preference in TF and found that animals preferred grasses with greater NSC, but no specific sugar fraction influenced animal preference. Although the relationship between preference and herbage intake is nebulous, it is clear that livestock prefer grasses with greater total carbohydrates and WSC (Mayland et al., 2000; Cougnon et al., 2018). Overall, our study indicated that inherently greater carbohydrate and dietary energy concentrations in the herbage enhance grazing intake.

Birdsfoot Trefoil-related Characteristics (PC2). Previous researchers reported that dairy cattle grazing BFT monoculture pastures have greater herbage intake compared with those grazing grass pastures (Harris et al., 1998; Woodward et al., 2000; MacAdam et al., 2015). Our study adds to these reports by finding that BFT at a range of proportions in mixtures with grass was also correlated with increased herbage intake compared with grass monoculture (Tables 1 and 4). Waldron et al. (2020) recommended $30+\%$ BFT in mixtures for optimal livestock performance; in 2017, all + BFT treatments approached or exceeded this BFT 
proportion during rotations 2 and 3 . However, percent of BFT declined substantially from 2017 to 2018, with only PR+BFT consistently at or above the $30 \%$ level in both years (Supplemental Figure S4, https://dx.doi .org/10.17632/jkjf3kw6hg.1, Waldron, 2021). Nevertheless, our study indicated that BFT comprising just 14 to $41 \%$ of grass-BFT mixed herbage results in increased herbage intake compared with grass monoculture. Furthermore, PCA indicated that the CT, protein, and lignin concentrations were highly correlated with BFT proportion; as such, were positively correlated with differences among pasture treatments (Figure 2).

Piluzza et al. (2014) suggested that low levels of CT improve herbage intake, and we hypothesized that CT in the BFT would interact in a complementary way with inherently greater grass energy (e.g., WSC) to further increase herbage intake. This was partially validated, as WSC and ME were included as secondary traits in this tannin-containing $\mathrm{PC}$ (i.e., $\mathrm{PC} 2$ ), whereas the percent of $\mathrm{CT}$ in the herbage was also included as a secondary trait in the energy-related PC (i.e., PC1). Furthermore, within the +BFT treatments, there was a trend of increasing ME, WSC, and CT levels associated with increased herbage intake. However, the full effect of $\mathrm{CT}$ in this study was probably confounded by extremely low CT concentrations. Low levels of CT from forage legumes have been shown to improve protein-use efficiency and livestock performance (Min et al., 2003), but those benefits are usually realized at CT concentrations of 1 to $2.5 \%$ (MacAdam, 2019). This threshold CT concentration is double our $0.5 \% \mathrm{CT}$ in the $\mathrm{PR}+\mathrm{BFT}$ herbage, and 4 to 6 -times greater than that in other $+\mathrm{BFT}$ treatments. It is important to note that the BFT CT levels were similar among all +BFT treatments (Table 4), indicating that differences in \% $\mathrm{CT}$ in herbage were entirely due to differences in percent of BFT (as opposed to differential CT synthesis). Thus, inasmuch as $3+$ BFT treatments had greater $(P$ $<0.05)$ herbage intake than all other treatments, but also exhibited widely ranging percent of $\mathrm{CT}$ in herbage (0.15-0.48\%), it is impossible to draw a conclusion as to the effect of $\mathrm{CT}$ per se on grazing intake. Overall, the $\mathrm{PC} 2$ data supported that BFT proportion and its association with $\mathrm{CT}$ and $\mathrm{CP}$ influenced herbage intake by Jersey heifers.

Moore et al. (1999) found that CP increased ruminant intake when TDN:CP ratio was greater than 7 (e.g., deficient in nitrogen). In our study, the TDN:CP ratio was 5.2 for $+\mathrm{BFT}$ and 7.2 for monoculture pasture types, with ratios of $7.1,6.8,7.3$, and 7.5 for PR, MB, OG, and TF treatments, respectively. Fisher (2002) also reported that CP less than 6 to $9 \%$ was closely associated with forage intake, but that digestibility and NDF had greater influence on intake when protein was over $9 \%$. Average CP of our monoculture pastures was 9.7 and 8.6 in rotations 1 and 2, respectively, compared with 13.8 and 14.4 for mixtures. Therefore, it is likely that monoculture treatments experienced a $\mathrm{ME}: \mathrm{CP}$ imbalance such that they were deficient in CP, providing support for consistently lesser herbage intake of monocultures compared with their respective mixtures.

It has been hypothesized that superior cell wall digestibility (e.g., increased NDFD and reduced lignin) increases forage intake due to improved digestive passage rate; however, Brink and Soder (2011) were unable to validate this in several cool-season grasses varying in NDFD. In our study, NDFD was negatively associated with PC2, corresponding to greater NDFD on average in grass monocultures compared with grass + BFT mixtures (Table 4). Furthermore, $\mathrm{PR}+\mathrm{BFT}$ and $\mathrm{TF}+\mathrm{BFT}$ pastures had less $(P<0.05)$ NDFD and all individual grass-BFT mixtures exhibited up to $64 \%$ greater $(P$ $<0.05)$ highly indigestible lignin (ADL) than their respective grass monocultures, making these results counter-intuitive to the greater herbage intake observed for all grass+BFT pastures. Overall, these results indicate that the effect of percent of BFT masked any putative positive effects of improved cell wall digestibility on grazing intake.

Herbage Allowance, Height, and Fructan (PC3). The importance of herbage allowance on herbage intake has been well documented in the literature (Vazquez and Smith, 2000; Sollenberger et al., 2005; Baudracco et al., 2010; Sollenberger and Vanzant, 2011; Baudracco et al., 2013). In general, at low herbage allowance, nonnutritional factors such as herbage mass largely drive herbage intake; as such, intake by cattle increases as herbage allowance increases (Baudracco et al., 2010; Sollenberger and Vanzant, 2011). In contrast, at high herbage allowance, increased herbage mass has little effect, whereas herbage nutritional factors largely control herbage intake (Baudracco et al., 2010; Sollenberger and Vanzant, 2011). For instance, Bargo et al. (2002) showed that as herbage allowance increased from 20 to $40 \mathrm{~kg}$ of herbage mass/cow per day (i.e., based upon 631-kg cow and a 20-d grazing period equivalent to 0.79 and $1.27 \mathrm{~kg}$ of herbage mass $/ \mathrm{kg}$ BW, respectively), herbage intake also increased from 2.9 to $3.4 \%$ of BW of dairy cattle. In contrast, Brink and Soder (2011) evaluated Holstein heifers grazing in Wisconsin and found no relationship between herbage intake and herbage allowance. They noted that they purposely set herbage allowance high (i.e., based upon the spring and summer data equivalent to 0.99 to 1.97 $\mathrm{kg}$ of herbage mass $/ \mathrm{kg}$ of BW) for ad libitum intake to reduce the confounding effect of herbage allowance on the intake-sward structure relationships. Likewise, we also purposely used low stocking rates to reduce the 
confounding of grasses varying widely in herbage mass on the intake-herbage nutritive value relationship. As such, our herbage allowance (i.e., 1.51 and $1.93 \mathrm{~kg}$ of herbage mass $/ \mathrm{kg}$ of $\mathrm{BW}$, for monocultures and BFT mixtures, respectively) are similar to theirs and also suggest ad libitum intake with only 35 and $34 \%$ utilization of the grass-BFT and grass-monoculture pastures, respectively. Thus, it is not surprising that $\mathrm{PC} 3$, which is largely driven by herbage allowance, only explained $19 \%$ of the variation among pasture treatments. Nevertheless, PC3 was a significant factor $(P<0.001)$ associated with herbage intake in multiple regression, and every grass-BFT mixture had greater $(P<0.05)$ herbage allowance and corresponding greater herbage intake than their respective grass monocultures. Even so, it is possible that differences in herbage allowance among pasture treatments still partially confounded the actual relationship between nutritional value and $+\mathrm{BFT}$ on herbage intake. Future grazing studies with these pasture species and mixtures at a similar herbage allowance for all treatments (preferably approaching ad libitum herbage intake) would exclude this confounding and help elucidate how the inherent differences among these treatments in nutritional value and $+\mathrm{BFT}$ are associated with herbage intake.

The inclusion of herbage height with herbage allowance in this PC is consistent with other studies. For instance, Tharmaraj et al. (2003) reported that herbage intake was not only greater in PR swards with herbage allowance of $70 \mathrm{~kg}$ of herbage mass/cow per day compared with $35 \mathrm{~kg}$ of herbage mass/cow per day, but that intake increased in both herbage allowance regimens when pre-grazing herbage height went from 14 to $28 \mathrm{~cm}$. In comparison, we observed that pregrazing herbage height for all $+\mathrm{BFT}$ treatments were taller on average by $3.8 \mathrm{~cm}$ and had greater herbage intake than their respective monocultures. Fructans are a subcomponent of total NSC, which are generally positively associated with livestock preference (Mayland et al., 2000). Thus, the biplot contrast of fructan with the herbage allowance-height complex makes fructan's inclusion in PC3 counter-intuitive, especially given that all + BFT treatments, except for PR + BFT, had greater herbage allowance, herbage height, and fructan than their respective monocultures. These results suggested that the PR treatment, which had the greatest fructan levels but also the least herbage allowance and herbage height, was the primary driver of fructan's inclusion in PC3, making fructan's association with our herbage intake inconclusive.

Fats (PC4). The PC4 only explained 6 of the variation among treatments, but was still a significant contributor to our regression model and identified fatty acids as contributing herbage characteristic not previously discussed. Bargo et al. (2003) conducted an extensive review and concluded that fat-supplemented dairy cows on pasture generally do not significantly differ in DMI compared with nonsupplemented animals. Likewise, on average, grass-monoculture pastures had greater $(P<0.05)$ fat (as estimated by fatty acids), but lesser $(P<0.05)$ herbage intake than grass-BFT mixtures. Schroeder et al. (2004) also hypothesized that because typical pasture diets are relatively low in fat content, a growth response from minimal additional fat may be expected. Our heifers received all dietary fat from grazed herbage (ranging from 2-3\%), and perhaps as hypothesized (Schroeder et al., 2004), even minimal differences had an effect on herbage intake, especially in the $\mathrm{OG}$ and $\mathrm{OG}+\mathrm{BFT}$ treatments which exhibited greater $(P<0.05)$ fat in both monoculture and BFT mixture than the other monoculture and mixture pastures, respectively.

\section{CONCLUSIONS}

We observed differences among pasture treatments in herbage quantity and nutritive value, as well as differences in herbage intake by grazing Jersey heifers. The study showed that grass+BFT binary mixtures increased herbage intake over grass monocultures, regardless of the nutritive value of the grass. Approximately $50 \%$ of the variation in herbage intake was explained by nutritive and physical herbage characteristics, including primarily fiber and energy (NDF, ADF, NFC, ME, IVTD, and WSC) and those characteristics related to the proportion of $\mathrm{BFT}$ in the herbage $(\% \mathrm{BFT}, \%$ $\mathrm{CT}$ in herbage, ADL, CP, and NDFD). Grasses exhibited a range of inherent dietary energy, and there was evidence that resulting ME:CP imbalances (e.g., $\mathrm{CP}$ deficient) reduced intake of grass monocultures. We had hypothesized that $\mathrm{CT}$ in the birdsfoot trefoil would interact in a complementary way with greater energy in the grasses to increase herbage intake, which was partially validated by the high $\mathrm{CT}$ and ME treatment $(\mathrm{PR}+\mathrm{BFT})$ ranking first for herbage intake. However, 3 +BFT treatments had equivalent herbage intake, but widely ranging $\mathrm{CT}$ levels $(0.15-0.48 \%)$ making it impossible to determine the effect of $\mathrm{CT}$ on herbage intake per se. Overall, pastures consisting of binary mixtures of high-energy grasses and as little as $14 \%$ birdsfoot trefoil increased herbage intake by grazing Jersey heifers.

\section{ACKNOWLEDGMENTS}

This research was supported in part by the US Department of Agriculture, Agricultural Research Service (Washington, DC), and the USDA National Institute of 
Food and Agriculture (NIFA; Washington, DC) through (1) Western Sustainable Agriculture Research and Education program (WSARE) grant no. 2016-3864025383/subaward SW17-046 and (2) Organic Agriculture Research and Extension Initiative (OREI) grant no. 2017-51300-26866/project accession no UTA01375. The USDA is an equal opportunity employer and service provider. Mention of trade names or commercial products in this publication is solely for the purpose of providing specific information and does not imply recommendation or endorsement by the US Department of Agriculture or Utah State University. The authors have not stated any conflicts of interest.

\section{REFERENCES}

AgMRC. 2015. Estimated U.S. sales of organic and total fluid milk products, monthly and annual, 2006-13. Accessed Jul. 8, 2020. http://www.agmrc.org.

Allen, V. G., C. Batello, E. J. Berretta, J. Hodgson, M. Kothmann, X. Li, J. McIvor, J. Milne, C. Morris, A. Peeters, and M. Sanderson. 2011. An international terminology for grazing lands and grazing animals. Grass Forage Sci. 66:2-28. https://doi.org/10.1111/j.1365 $-2494.2010 .00780 . x$

Allison, C. D., M. M. Kothmann, and L. R. Rittenhouse. 1982. Efficiency of forage harvest by grazing cattle. J. Range Manage. 35:351-354. https://doi.org/10.2307/3898316.

Anon. 2020a. 5 reasons to eat organic. Accessed Jul. 9, 2020. https: //www.organicvalley.coop/why-organic-valley/5-reasons-eat -organic/.

Anon. 2020b. Livestock and poultry standards. Accessed Jul. 8, 2020. https://www.ams.usda.gov/grades-standards/organic-standards \#Livestock.

Bargo, F., L. D. Muller, J. E. Delahoy, and T. W. Cassidy. 2002. Milk response to concentrate supplementation of high producing dairy cows grazing at two pasture allowances. J. Dairy Sci. 85:17771792. https://doi.org/10.3168/jds.S0022-0302(02)74252-5 https:// doi.org/10.3168/jds.S0022-0302(02)74252-5.

Bargo, F., L. D. Muller, E. S. Kolver, and J. E. Delahoy. 2003. Invited review: Production and digestion of supplemented dairy cows on pasture. J. Dairy Sci. 86:1-42. https://doi.org/10.3168/jds.S0022 $-0302(03) 73581-4$

Baudracco, J., E. A. Comeron, N. L. Villalobos, L. A. Romero, D. Scandolo, T. N. Barry, and C. W. Holmes. 2013. Effects of herbage allowance on dry matter intake, efficiency of grazing, milk yield and grazing behaviour of crossbred Holstein-Jersey dairy cows grazing alfalfa pastures. J. Adv. Dairy Res. 2. https://doi.org/10 .4172/2329-888X.1000109.

Baudracco, J., N. Lopez-Villalobos, C. W. Holmes, and K. A. Macdonald. 2010. Effects of stocking rate, supplementation, genotype and their interactions on grazing dairy systems: A review. N. Z. J. Agric. Res. 53:109-133. https://doi.org/10.1080/00288231003777665.

Belesky, D. P., and J. M. Fedders. 1994. Defoliation effects on seasonal production and growth rate of cool-season grasses. Agron. J. 86:3845. https://doi.org/10.2134/agronj1994.00021962008600010008x.

Bonesmo, H., and A. O. Skjelvåg. 1999. Regrowth rates of timothy and meadow fescue cut at five phenological stages. Acta Agric. Scand. B Soil Plant Sci. 49:209-215. https://doi.org/10.1080/713782028.

Bransby, D. I. 1989. Compromises in the design and conduct of grazing experiments. Pages 69-84 in Grazing research: Design, methodology, and analysis. G. C. Marten, ed. Agronomy Society of America and Crop Science Society of America.

Brink, G. E., and K. J. Soder. 2011. Relationship between herbage intake and sward structure of grazed temperate grasses. Crop Sci. 51:2289-2298. https://doi.org/10.2135/cropsci2010.10.0600.
Cosgrove, G. P., J. L. Burke, A. F. Death, M. J. Hickey, D. Pacheco, and G. A. Lane. 2007. Ryegrasses with increased water soluble carbohydrate: Evaluating the potential for grazing dairy cows in New Zealand. Proc. N. Z. Grassl. Assoc. 69:179-185. https://doi .org/https://doi.org/10.33584/jnzg.2007.68.2659.

Cosgrove, G. P., N. R. Mapp, P. S. Taylor, B. M. Harvey, and K. J. Knowler. 2014. The chemical composition of high-sugar and control ryegrasses in grazed pastures at different latitudes throughout New Zealand. Proc. N. Z. Grassl. Assoc. 76:169-176.

Cougnon, M., R. Shahidi, J. Schoelynck, I. Van Der Beeten, C. Van Waes, P. De Frenne, M. C. Van Labeke, and D. Reheul. 2018. Factors affecting grazing preference by sheep in a breeding population of tall fescue (Festuca arundinacea Schreb.). Grass Forage Sci. 73:330-339. https://doi.org/10.1111/gfs.12340.

Cox, S., M. D. Peel, J. E. Creech, B. L. Waldron, J.-S. Eun, D. R. Zobell, R. L. Miller, and D. L. Snyder. 2017. Forage production of grass-legume binary mixtures on intermountain western USA irrigated pastures. Crop Sci. 57:1742-1753. https://doi.org/10.2135/ cropsci2016.04.0235.

Dillard, S. L., A. N. Hafla, M. D. Rubano, R. C. Stout, A. F. Brito, and K. J. Soder. 2016. Evaluation of a rising plate meter for use in multispecies swards. Agric. Environ. Lett. 1:160032. https://doi .org/10.2134/ael2016.08.0032.

Edwards, G. R., A. J. Parsons, S. Rasmussen, and R. H. Bryant. 2007. High sugar ryegrasses for livestock systems in New Zealand. Proc. N. Z. Grassl. Assoc. 69:161-171.

Fisher, D. S. 2002. A review of a few key factors regulating voluntary feed intake in ruminants. Crop Sci. 42:1651-1655. https://doi.org/ 10.2135/cropsci2002.1651.

Giesbrecht, F. G. 1989. Experimental design and statistical inference: Generalized least squares and repeated measures over time. Pages 85-96 in Grazing Research: Design, Methodology, and Analysis. G. C. Marten, ed. Agronomy Society of America, Crop Science Society of America.

Grabber, J. H., W. K. Coblentz, H. Riday, T. C. Griggs, D. H. Min, J. W. MacAdam, and K. A. Cassida. 2015. Protein and dry-matter degradability of European- and Mediterranean-derived birdsfoot trefoil cultivars grown in the colder continental USA. Crop Sci. 55:1356-1364. https://doi.org/10.2135/cropsci2014.09.0659.

Grabber, J. H., H. Riday, K. A. Cassida, T. C. Griggs, D. H. Min, and J. W. MacAdam. 2014. Yield, morphological characteristics, and chemical composition of European- and Mediterranean-derived birdsfoot trefoil cultivars grown in the colder continental United States. Crop Sci. 54:1893-1901. https://doi.org/10.2135/ cropsci2013.09.0644.

Hadfield, J. A., B. L. Waldron, S. C. Isom, J. E. Creech, M. F. Rose, J. Long, R. L. Miller, K. A. Rood, A. Young, R. Stott, A. Sweat, and K. J. Thornton. 2021. The effects of organic grass and grass-birdsfoot trefoil pastures on dairy heifer development: Heifer growth, performance, and economic impact. J. Dairy Sci. 104:10863-10878. https://doi.org/10.3168/jds.2021-19524.

Harris, S. L., D. A. Clark, and P. J. Laboyrie. 1998. Birdsfoot trefoil - An alternative legume for New Zealand dairy pastures. Proc. N. Z. Grassl. Assoc. 60:99-103. https://doi.org/https://doi.org/10 $.33584 /$ jnzg.1998.60.2314.

Hoveland, C. S., D. R. Hardin, P. C. Worley, and E. E. Worley. 1991 Steer performance on perennial vs winter annual pastures in north Georgia. J. Prod. Agric. 4:24-28. https://doi.org/10.2134/jpa1991 .0024 .

Hoveland, C. S., R. R. Harris, E. E. Thomas, E. M. Clark, J. A. Mcguire, J. T. Eason, and M. E. Ruf. 1981. Tall fescue with ladino clover or birdsfoot-trefoil as pasture for steers in northern Alabama. Pages 3-11 in Ala. Agric. Exp. Sta. Bull. Auburn University.

Jensen, K., H. Horton, R. Reed, and R. Whitesides. 2001. Intermountain planting guide. Accessed Nov. 20, 2020. https:// digitalcommons.usu.edu/extension_curall/1333.

Kassambara, A. and F. Mundt. 2020. factoextra: extract and visualize the results of multivariate data analyses. Page R package. 1.0.7 ed. https://CRAN.R-project.org/package=factoextra. 
Kolver, E. S., and L. D. Muller. 1998. Perfomance and nutrient intake of high producing holstein cows consuming pasture or a total mixed ration. J. Dairy Sci. 81:1403-1411. https://doi.org/10.3168/ jds.S0022-0302(98)75704-2.

Lee, M. R. F., L. J. Harris, J. M. Moorby, M. O. Humphreys, M. K. Theodorou, J. C. MacRae, and N. D. Scollan. 2002. Rumen metabolism and nitrogen flow to the small intestine in steers offered Lolium perenne containing different levels of water-soluble carbohydrate. Anim. Sci. 74:587-596. https://doi.org/10.1017/ S1357729800052747.

Littell, R. C., G. A. Milliken, W. W. Stroup, and R. D. Wolfinger. 2006. SAS for Mixed Models. 2nd ed. SAS Institute Inc.

MacAdam, J. W. 2019. The value of condensed tannins in forages: Overview of the symposium. Crop Sci. 59:858-860. https://doi .org/10.2135/cropsci2018.02.0135.

MacAdam, J. W., S. R. Hunt, T. C. Griggs, R. Christensen, J.-S. Eun, R. E. Ward, and D. J. McMahon. 2015. Enhanced forage intake and milk production on birdsfoot trefoil pastures in the western U.S. In Proc. Organic Agriculture Research Symposium.

Macoon, B., L. E. Sollenberger, J. E. Moore, C. R. Staples, J. H. Fike, and K. M. Portier. 2003. Comparison of three techniques for estimating the forage intake of lactating dairy cows on pasture. J. Anim. Sci. 81:2357-2366. https://doi.org/10.2527/2003.8192357x.

Mallarino, A. P., W. F. Wedin, C. H. Perdomo, R. S. Goyenola, and C. P. West. 1990. Nitrogen transfer from white clover, red clover, and birdsfoot trefoil to associated grass. Agron. J. 82:790-795. https:// doi.org/10.2134/agronj1990.00021962008200040027x.

Mayland, H. F., G. E. Shewmaker, P. A. Harrison, and N. J. Chatterton. 2000. Nonstructural carbohydrates in tall fescue cultivars: Relationship to animal preference. Agron. J. 92:1203-1206. https: //doi.org/10.2134/agronj2000.9261203x.

McBride, W., and C. Greene. 2009. Characteristics, costs and issues for organic dairy farming. Accessed Jul. 7, 2020. https://www .ers.usda.gov/webdocs/publications /46267/11004_err82_1_.pdf $? \mathrm{v}=41079 \% 3 \mathrm{E} \#: \sim:$ text $=$ milk\% $20 \mathrm{in} \% 202005 .-$, Challenges $\% 20$ of \%20Organic\%20Milk\%20Production.,production\%2C\%20and\%20 maintaining\%20animal\%20health

Miller, L. A., J. M. Moorby, D. R. Davies, M. O. Humphreys, N. D. Scollan, J. C. MacRae, and M. K. Theodorou. 2001. Increased concentration of water-soluble carbohydrate in perennial ryegrass (Lolium perenne L.): milk production from late-lactation dairy cows. Grass Forage Sci. 56:383-394. https://doi.org/10.1046/j.1365-2494 2001.00288.x.

Min, B. R., T. N. Barry, G. T. Attwood, and W. C. McNabb. 2003. The effect of condensed tannins on the nutrition and health of ruminants fed fresh temperate forages: A review. Anim. Feed Sci. Technol. 106:3-19. https://doi.org/10.1016/S0377-8401(03)00041 -5 .

Moorby, J. M., R. T. Evans, N. D. Scollan, J. C. MacRae, and M. K. Theodorou. 2006. Increased concentration of water-soluble carbohydrate in perennial ryegrass (Lolium perenne L.). Evaluation in dairy cows in early lactation. Grass Forage Sci. 61:52-59. https:// doi.org/10.1111/j.1365-2494.2006.00507.x.

Moore, J. E., M. H. Brant, W. E. Kunkle, and D. I. Hopkins. 1999. Effects of supplementation on voluntary forage intake, diet digestibility, and animal performance. J. Anim. Sci. 77(Suppl 2):122-135. https://doi.org/10.2527/1999.77suppl_2122x.

Moore, K. J., L. E. Moser, K. P. Vogel, S. S. Waller, B. E. Johnson, and J. F. Pedersen. 1991. Describing and quantifying growth stages of perennial forage grasses. Agron. J. 83:1073-1077. https://doi .org/10.2134/agronj1991.00021962008300060027x.

Noviandi, C. T., J. S. Eun, M. D. Peel, B. L. Waldron, B. R. Min, D. R. ZoBell, and R. L. Miller. 2014a. Effects of energy supplementation in pasture forages on in vitro ruminal fermentation characteristics in continuous cultures. Prof. Anim. Sci. 30:13-22. https://doi .org/10.15232/S1080-7446(15)30077-2.

Noviandi, C. T., K. Neal, J. S. Eun, M. D. Peel, B. L. Waldron, D. R. ZoBell, and B. R. Min. 2014b. Comparison of alfalfa, birdsfoot trefoil, and cicer milkvetch in combination with 25,50 , or $75 \%$ tall fescue in a continuous-culture system. Prof. Anim. Sci. 30:23-32. https://doi.org/10.15232/S1080-7446(15)30078-4.
Noviandi, C. T., B. L. Waldron, J. S. Eun, D. R. ZoBell, R. D. Stott, and M. D. Peel. 2012. Growth performance, ruminal fermentation profiles, and carcass characteristics of beef steers grazing tall fescue without or with nitrogen fertilization. Prof. Anim. Sci. 28:519527. https://doi.org/10.15232/S1080-7446(15)30400-9.

NRC. 2000. Nutrient requirements of beef cattle: Seventh revised edition: Update 2000. The National Academies Press.

Nyfeler, D., O. Huguenin-Elie, M. Suter, E. Frossard, and A. Lüscher. 2011. Grass-legume mixtures can yield more nitrogen than legume pure stands due to mutual stimulation of nitrogen uptake from symbiotic and non-symbiotic sources. Agric. Ecosyst. Environ. 140:155-163. https://doi.org/10.1016/j.agee.2010.11.022.

Parsons, A. J., S. Rasmussen, H. Xue, J. A. Newman, C. B. Anderson, and G. P. Cosgrove. 2004. Some 'high sugar grasses' don't like it hot. Proc. N. Z. Grassl. Assoc. 66:265-271. https://doi.org/https: //doi.org/10.33584/jnzg.2004.66.2543.

Piluzza, G., L. Sulas, and S. Bullitta. 2014. Tannins in forage plants and their role in animal husbandry and environmental sustainability: A review. Grass Forage Sci. 69:32-48. https://doi.org/10 $.1111 /$ gfs. 12053.

Ribeiro Filho, H. M. N., R. Delagarde, and J. L. Peyraud. 2003. Inclusion of white clover in strip-grazed perennial ryegrass swards: Herbage intake and milk yield of dairy cows at different ages of sward regrowth. Anim. Sci. 77:499-510. https://doi.org/10.1017/ S1357729800054448.

Ribeiro Filho, H. M. N., R. Delagarde, and J. L. Peyraud. 2005. Herbage intake and milk yield of dairy cows grazing perennial ryegrass swards or white clover/perennial ryegrass swards at low- and medium-herbage allowances. Anim. Feed Sci. Technol. 119:13-27. https://doi.org/10.1016/j.anifeedsci.2004.12.009.

Robins, J., B. Bushman, U. Feuerstein, and G. Blaser. 2016. Variation and correlations among European and North American orchardgrass germplasm for herbage yield and nutritive value. Agronomy (Basel) 6:61. https://doi.org/10.3390/agronomy6040061.

Robins, J. G., and J. Alan Lovatt. 2016. Cultivar by environment effects of perennial ryegrass cultivars selected for high water soluble carbohydrates managed under differing precipitation levels. Euphytica 208:571-581. https://doi.org/10.1007/s10681-015-1607-9.

Robins, J. G., B. S. Bushman, K. B. Jensen, S. Escribano, and G. Blaser. 2015. Genetic variation for dry matter yield, forage quality, and seed traits among the half-sib progeny of nine orchardgrass germplasm populations. Crop Sci. 55:275-283. https://doi.org/10 .2135 /cropsci2014.04.0307.

Saha, U. K., L. S. Sonon, D. W. Hancock, N. S. Hill, L. Stewart, G. L. Heusner, and D. E. Kissel. 2010. Common terms used in animal feeding and nutrition. Accessed Apr. 12, 2021. https://extension .uga.edu/publications/detail.html? number $=$ B1367\#.

Schroeder, G. F., G. A. Gagliostro, F. Bargo, J. E. Delahoy, and L. D. Muller. 2004. Effects of fat supplementation on milk production and composition by dairy cows on pasture: A review. Livest. Prod. Sci. 86:1-18. https://doi.org/10.1016/S0301-6226(03)00118-0.

Smart, A. J., J. D. Derner, J. R. Hendrickson, R. L. Gillen, B. H. Dunn, E. M. Mousel, P. S. Johnson, R. N. Gates, K. K. Sedivec, K. R. Harmoney, J. D. Volesky, and K. C. Olson. 2010. Effects of grazing pressure on efficiency of grazing on North American Great Plains rangelands. Rangeland Ecol. Manag. 63:397-406. https:// doi.org/10.2111/REM-D-09-00046.1.

Smith, K. F., A. Stewart, and G. Spangenberg. 2007. Breeding high energy grasses for Australia and New Zealand. Proc. N. Z. Grassl. Assoc. 69:173-177. https://doi.org/https://doi.org/10.33584/jnzg 2007.69.2657.

Sollenberger, L. E., J. E. Moore, V. G. Allen, and C. G. S. Pedreira. 2005. Reporting forage allowance in grazing experiments. Crop Sci. 45:896-900. https://doi.org/10.2135/cropsci2004.0216.

Sollenberger, L. E., and E. S. Vanzant. 2011. Interrelationships among forage nutritive value and quantity and individual animal performance. Crop Sci. 51:420-432. https://doi.org/10.2135/cropsci2010 .07 .0408 .

Stakelum, G., and P. Dillon. 2003. The effect of concentrate type on herbage intake, diet composition and grazing behaviour of dairy 
cows and the association with sward characteristics. Ir. J. Agric. Food Res. 42:55-70.

Stephenson, R. J., and G. L. Posler. 1988. The influence of tall fescue on the germination, seedling growth and yield of birdsfoot trefoil. Grass Forage Sci. 43:273-278. https://doi.org/10.1111/j.1365-2494 .1988.tb02152.x.

Tharmaraj, J., W. J. Wales, D. F. Chapman, and A. R. Egan. 2003. Defoliation pattern, foraging behaviour and diet selection by lactating dairy cows in response to sward height and herbage allowance of a ryegrass-dominated pasture. Grass Forage Sci. 58:225238. https://doi.org/10.1046/j.1365-2494.2003.00374.x.

Utah Climate Center. 2018. Accessed Jul. 7, 2020. https://climate.usu .edu/index.php.

Vazquez, O. P., and T. R. Smith. 2000. Factors affecting pasture intake and total dry matter intake in grazing dairy cows. J. Dairy Sci. 83:2301-2309. https://doi.org/10.3168/jds.S0022-0302(00)75117 -4 .

Venables, W. N., and B. D. Ripley. 2002. Modern applied statistics with S. Fourth ed. Springer.

Waghorn, G. C. 2007. What is dietary metabolisable energy? Proc. N. Z. Grassl. Assoc. 69:153-159. https://doi.org/10.33584/jnzg.2007 .69.2676.

Waldo, D. R. 1986. Effect of forage quality on intake and forageconcentrate interactions. J. Dairy Sci. 69:617-631. https://doi. org/10.6084/m9.figshare.16441266.v1.

Waldron, B. 2021. Supplemental files for JDS 19563: The effects of organic grass and grass-birdsfoot trefoil pastures on Jersey heifer development: Herbage characteristics affecting intake. https://doi. org $/ 10.6084 / \mathrm{m} 9$.figshare.16441266.v1.

Waldron, B. L., T. J. Bingham, J. E. Creech, M. D. Peel, R. Miller, K. B. Jensen, D. R. ZoBell, J.-S. Eun, K. Heaton, and D. L. Snyder. 2020. Binary mixtures of alfalfa and birdsfoot trefoil with tall fescue: Herbage traits associated with the improved growth performance of beef steers. Grassl. Sci. 66:74-87. https://doi.org/ 10.1111 /grs. 12257.

Wen, L., R. L. Kallenbach, J. E. Williams, C. A. Roberts, P. R. Beuselinck, R. K. McGraw, and H. R. Benedict. 2002. Performance of steers grazing rhizomatous and nonrhizomatous birdsfoot trefoil in pure stands and in tall fescue mixtures. J. Anim. Sci. 80:19701976. https://doi.org/10.2527/2002.8071970x.

Wilson, J. R. 1994. Cell wall characteristics in relation to forage digestion by ruminants. J. Agric. Sci. 122:173-182. https://doi.org/10 $.1017 /$ S0021859600087347.

Woodward, S. L., P. J. Laboyrie, and E. B. L. Jansen. 2000. Lotus corniculatus and condensed tannins - Effects on milk production by dairy cows. Asian-Australas. J. Anim. Sci. 13:521-525.

Yeater, K. M., and M. B. Villamil. 2017. Multivariate methods for agricultural research. Pages 371-400 in Applied Statistics in Agricultural, Biological, and Environmental Sciences. B. Glaz and K. M. Yeater, ed. American Society of Agronomy, Crop Science Society of America, and Soil Science Society of America Inc.

\section{ORCIDS}

Marcus F. Rose ๑ https://orcid.org/0000-0002-9553-7796

Blair L. Waldron (ํ) https://orcid.org/0000-0003-3735-5326

S. Clay Isom ๑ https://orcid.org/0000-0001-6029-6753

Michael D. Peel $\odot$ https://orcid.org/0000-0002-3122-5486

Kara J. Thornton @ https://orcid.org/0000-0002-7506-5293

Rhonda L. Miller • https://orcid.org/0000-0003-0620-6862

Kerry A. Rood $\odot$ https://orcid.org/0000-0001-6655-5381

Jacob A. Hadfield (ㄴ) https://orcid.org/0000-0002-8415-4191

Jennifer Long $\odot$ https://orcid.org/0000-0001-8805-0456

J. Earl Creech ๑ https://orcid.org/0000-0002-4393-6816 